\title{
Analysis of a bac operon-silenced strain suggests pleiotropic effects of bacilysin in Bacillus subtilis
}

\author{
Ozan Ertekin ${ }^{1}$, Meltem Kutnu', \\ Aslı Aras Taşkın ${ }^{1,3}$, Mustafa Demir ${ }^{1,4}$, \\ Ayten Yazgan Karataş ${ }^{2}$, and Gülay Özcengiz ${ }^{1 *}$ \\ ${ }^{1}$ Department of Biological Sciences/Molecular Biology and Genetics, \\ Middle East Technical University, Ankara, Turkey \\ ${ }^{2}$ Molecular Biology-Biotechnology and Genetics Research Center \\ (MOBGAM) and Molecular Biology and Genetics Department, \\ Istanbul Technical University, Istanbul, Turkey \\ ${ }^{3}$ Faculty of Biology and Spemann Graduate School of Biology and \\ Medicine, University of Freiburg, Freiburg, Germany \\ ${ }^{4}$ Biotechnology and Bioengineering, Ecole polytechnique fédérale de \\ Lausanne, Lausanne, Switzerland
}

(Received Feb 8, 2019 / Revised Dec 11, 2019 / Accepted Dec 24, 2019)

Bacilysin, as the simplest peptide antibiotic made up of only $\mathrm{L}$-alanine and L-anticapsin, is produced and excreted by Bacillus subtilis under the control of quorum sensing. We analyzed bacilysin-nonproducing strain OGU1 which was obtained by bacA-targeted pMutin T3 insertion into the parental strain genome resulting in a genomic organization (bac $A^{\prime}::$ lacZ::erm::bacABCDEF) to form an IPTG-inducible bac operon. Although IPTG induction provided 3- to 5-fold increment in the transcription of bac operon genes, no bacilysin activity was detectable in bioassays and inability of the OGU1 to form bacilysin was confirmed by UPLC-mass spectrometry analysis. Phenotypic analyses revealed the deficiencies in OGU1 with respect to colony pigmentation, spore coat proteins, spore resistance and germination, which could be rescued by external addition of bacilysin concentrate into its cultures. 2DE MALDI-TOF/MS and nanoLC-MS/MS were used as complementary approaches to compare cytosolic proteomes of OGU1. 2-DE identified 159 differentially expressed proteins corresponding to 121 distinct ORFs. In nanoLCMS/MS, 76 proteins were differentially expressed in OGU1. Quantitative transcript analyses of selected genes validated the proteomic findings. Overall, the results pointed to the impact of bacilysin on expression of certain proteins of sporulation and morphogenesis; the members of mother cell compartment-specific $\sigma^{\mathrm{E}}$ and $\sigma^{\mathrm{K}}$ regulons in particular, quorum sensing and two component-global regulatory systems, peptide transport, stress response as well as CodY- and ScoCregulated proteins.

Keywords: Bacillus subtilis, bacilysin, bac operon, sporula-

*For correspondence. E-mail: ozcengiz@metu.edu.tr; Tel.: +90-31-2210-

5170; Fax: +90-31-2210-7976

${ }^{8}$ Supplemental material for this article may be found at

http://www.springerlink.com/content/120956.

Copyright (C) 2020, The Microbiological Society of Korea tion, chemical complementation, pleiotropy, comparative proteomics, RT-qPCR

\section{Introduction}

As an enzymatically synthesized dipeptide first identified from Bacillus subtilis, bacilysin is made up of L-alanine and the non-proteinogenic amino acid, L-anticapsin (Walker and Abraham, 1970), the latter being responsible for its antibiotic action in susceptible bacterial and fungal cells (Kenig et al., 1976; Milewsky et al., 1986). ywfBCDEFG operon, and the monocistronic gene $y w f H$ together encode the enzymes of pathway leading to anticapsin and bacilysin (Inaoka et al., 2003). These genes showing up to $88.6 \%$ sequence identity from different Bacillus species were renamed as bacABCDEF and $b a c G$, for further use in genetic, biochemical and biophysical studies (Steinborn et al., 2005; Rajavel et al., 2009; Mahlstedt and Walsh, 2010; Parker and Walsh, 2012, 2013; Shomura et al., 2012). Of these genes, only bacE is not involved in bacilysin formation, but its product pumps out bacilysin to prevent suicide (Steinborn et al., 2005).

As recently reviewed (Özcengiz and Öğülür, 2015) (Fig. 1), bacilysin biosynthesis is one of the targets of quorum sensing control in its producer, requiring the functions of ComQ/ ComX, Phr peptides C, F and K, ComP/ComA, Spo0K (Opp) and srfA operon (Yazgan et al., 2001; Karataş et al., 2003). As to the other elements operating in the regulatory circuit of bacilysin formation, Inaoka et al. (2003) reported the involvement of ppGpp and GTP in transcriptional regulation of bac operon in a pleiotropic CodY repressor-mediated manner, and then their finding on regulation of the operon by the transition state transcriptional repressor ScoC (Hpr) (Inaoka et al., 2009). While there is a competition between two key activators, ComA and Spo0A for bac operon promoter $\left(\mathrm{P}_{b a c}\right)$, the negative transcriptional regulators $\mathrm{Abr} B$ and CodY simultaneously bind to $\mathrm{P}_{b a c}$ (Köroğlu et al., 2011). The DegS/DegU two-component signal transduction system is also involved in positive regulation of bac operon and bacG, as shown in B. amyloliquefaciens (Mariappan et al., 2012).

Since the complete B. subtilis 168 genome sequence was first published (Kunst et al., 1997) and updated (Barbe et al., 2009), much effort has been devoted to deeply understand the physiology of this model organism by postgenomic studies. For instance, proteomics has been widely used in order to visualize the responses of $B$. subtilis cells to various types of stimuli like oxidative stress and nutrient starvation, elucidating the relevant gene expression networks (Hecker et al., 2009). 


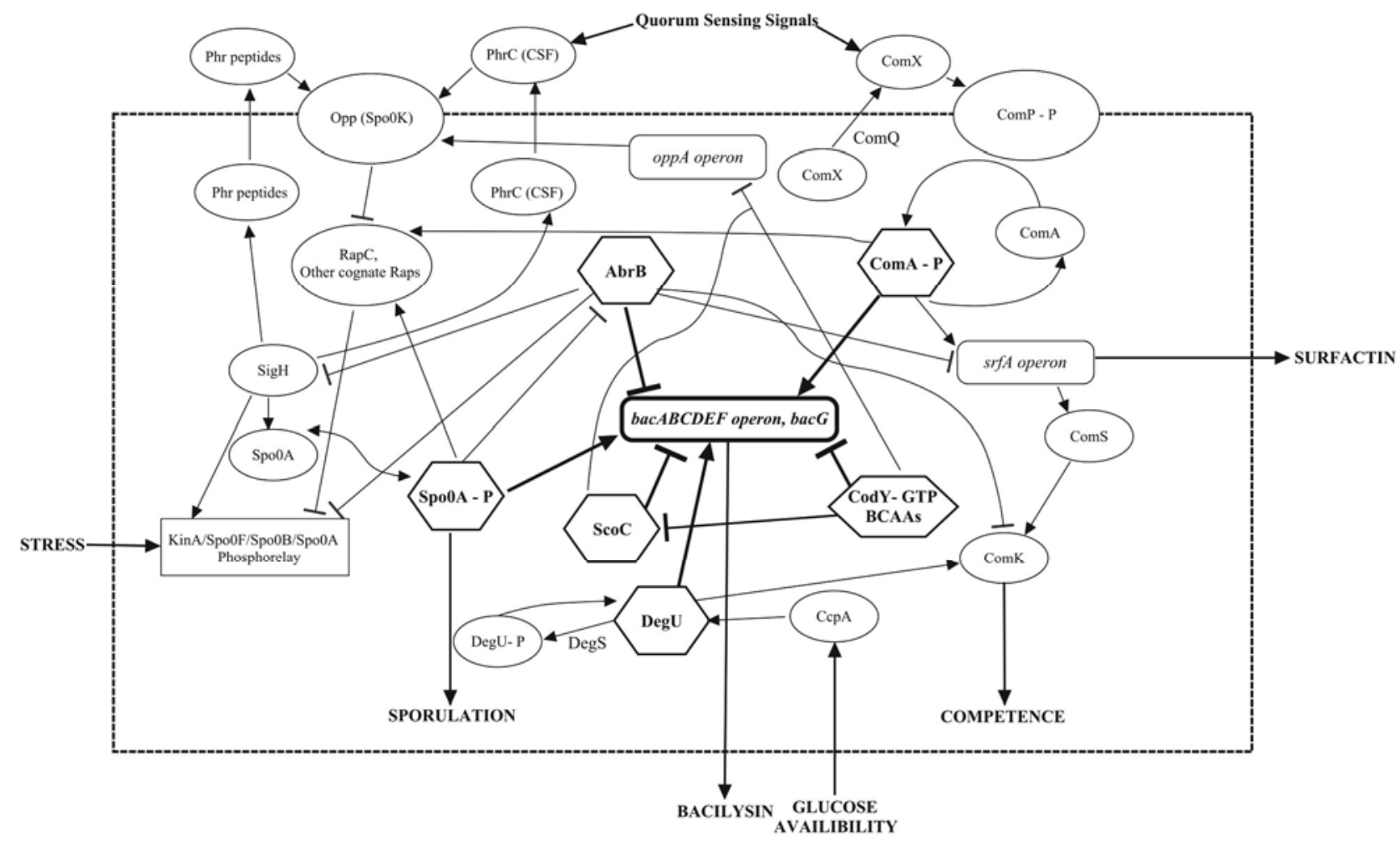

Fig. 1. Molecular regulation of bacilysin biosynthetic bac operon. Quorum sensing system and pleiotropic regulators that cross-link bacilysin biosynthesis with surfactin biosynthesis, competence development and sporulation in response to quorum sensing signals, stress and glucose availability. Arrows indicate activation; repression is denoted by T-bars. Bold lines refer to direct interaction with $\mathrm{P}_{b a c}$ (adopted from Özcengiz and Ögülür, 2015).

The complexity of the regulation of bacilysin formation brings up the question of whether bacilysin itself has some role(s) in its producer and how B. subtilis cells physiologically respond to the loss of bacilysin biosynthetic function. In the present study, we showed that a bacilysin biosynthetic operon-silenced mutant, namely OGU1 (Köroğlu et al., 2011), exhibited deficiencies in colony pigmentation, spore coat protein profile, spore resistance and germination. Externally added bacilysin concentrate provided chemical complementation and restored wild-type phenotype in this strain. A view of the alterations in cytosolic proteome was obtained by identifying differentially expressed proteins in this mutant by employing $2 \mathrm{DE}$ - and nanoLC proteomics as complementary approaches and validated by quantitative transcript analysis for the selected genes. The data presented herein document a variety of pleiotropic effects resulting from the loss of bacilysin biosynthesis.

\section{Materials and Methods}

\section{Bacillus subtilis strains and the cultures}

B. subtilis PY79 (Youngman et al., 1984) and its bacilysin-nonproducer (bacA'::lacZ::erm::bacABCDEF) derivative OGU1 (Köroğlu et al., 2011) were the strains used throughout this study. PA medium (Perry and Abraham, 1979) without any antibiotics was the principal cultivation medium for suspended cultures. For OGU1, erythromycin and lincomycin were incorporated into LA (Luria Agar) cultures and their concentrations were as in Köroğlu et al. (2011). Fresh LA cultures of the strains were used to inoculate the cells into $10 \mathrm{ml}$ of PA medium. The cultures grown overnight at $37^{\circ} \mathrm{C}$ by shaking were then inoculated into $100 \mathrm{ml}$ of PA medium to an initial $\mathrm{OD}_{595}$ of 0.1 and subsequent cultivation was done by shaking at $37^{\circ} \mathrm{C}(200 \mathrm{rpm})$ for $16 \mathrm{~h}$.

\section{IPTG induction of OGU1 cultures}

Three different experiments were conducted for IPTG induction of $b a c$ operon in OGU1. Hundred milliliter of PA medium without any antibiotics were inoculated with OGU1 overnight cultures to an initial $\mathrm{OD}_{595}$ of 0.1 . In the first set of experiments, IPTG induction was made by adding $1 \mathrm{mM}$ IPTG to the culture at $8^{\text {th }} \mathrm{h}$. The samples were collected at $12^{\text {th }}, 14^{\text {th }}$, and $16^{\text {th }} \mathrm{h}$ for detection of bacilysin activity by bioassays. In the second set of experiments, an $8^{\text {th }} \mathrm{h}$ OGU1 culture received $1 \mathrm{mM}$ IPTG to which $0.5 \mathrm{mM}$ IPTG was re-added when it reached to $14^{\text {th }} \mathrm{h}$. The samplings for the determination of bacilysin activity were made at $16^{\text {th }}, 18^{\text {th }}$, and $20^{\text {th }} \mathrm{h}$. In the third round of experiments, $1 \mathrm{mM}$ IPTG was administered to $15^{\text {th }} \mathrm{h}$ cultures from which the samples were withdrawn after $20,30,40,60$, and $80 \mathrm{~min}$, respectively, for bioassays. In all of the experiments mentioned above, PY79 and uninduced OGU1 cultures were also run in parallel and the samples were collected at the same time intervals as the positive and negative controls, respectively. 


\section{Bacilysin bioassay}

Bacilysin activity in culture fluids was determined by the paper disc-agar diffusion assay using S. aureus ATCC 9144 as the test organism and the antibiotic activity was estimated as in Özcengiz et al. (1990).

\section{Ultra-performance liquid chromatography-mass spectrom- etry (UPLC-MS) analysis}

Two hundred microliter of culture supernatants were extracted with one-fourth volume of butanol and lyophilized to dryness. After dissolved in $10 \mu \mathrm{l}$ of a solvent mixture $\left(\mathrm{H}_{2} \mathrm{O}\right.$ : $5 \% \mathrm{CH}_{3} \mathrm{CN}+1 \% \mathrm{HCOOH}$ ), samples were analyzed by UPLCMS (Waters Acquity UPLC H-Class and Water Synapt G2-Si HDMS) at the positive detection mode. $7.5 \mu \mathrm{l}$ of sample was injected onto a Waters Acquity Peptide BEH C18 column $(2.1 \mathrm{~mm} \times 100 \mathrm{~mm})$ equilibrated in solution mixture $(1 \%$ $\mathrm{CH}_{3} \mathrm{CN}+0.1 \% \mathrm{HCOOH}+\mathrm{H}_{2} \mathrm{O}$ ) with a flow rate $0.2 \mathrm{ml} /$ $\mathrm{min}$, and column temperature was kept at $65^{\circ} \mathrm{C}$. Bound compounds were eluted with a gradient prepared with Solution A $\left(0.1 \% \mathrm{HCOOH}: \mathrm{H}_{2} \mathrm{O}\right)$ and Solution $\mathrm{B}\left(\mathrm{CH}_{3} \mathrm{CN}\right)$ as follows: $1 \%$ Solution B for $1 \mathrm{~min}, 1-40 \%$ of Solution B over $10 \mathrm{~min}$, $40-80 \%$ Solution B over $1 \mathrm{~min}$ and kept for $2 \mathrm{~min}, 80-1 \%$ of Solution B over $50 \mathrm{sec}$, and 1\% Solution B reequilibration for 10 min before loading the next sample.

\section{Whole genome resequencing (WGRS)}

WGRS of B. subtilis OGU1 and its parental strain PY79 were performed on individual colonies on Illumina Truseq in $2 \times$ $150 \mathrm{bp}$ paired end configuration (Macrogen, Inc.). Average coverage was $1-2 \mathrm{~Gb} /$ sample. The raw data were processed and aligned to reference genome of Bacillus Genetic Stock Center (BGSC)-deposited B. subtilis PY79 (DDBJ/EMBL/ GenBank databases with GenBank accession no. CP006881.1) with Burrows-Wheeler Aligner for SNPs and small indels analysis (Schroeder and Simmons, 2013). The data from OGU1 and its parental PY79 were deposited at DDBJ/ENA/ GenBank databases under the accession no. QLNM00000000.1 and WOWX00000000, respectively. SAMTools and Picard were used to remove duplicated reads and find variant information for further confirmation.

\section{Preparation of bacilysin concentrates and chemical com- plementation}

Bacilysin concentrates were prepared from $16 \mathrm{~h}$ PA cultures of PY79 as in Roscoe and Abraham (1966), sterilized by filtration, and kept in $-20^{\circ} \mathrm{C}$ until use. For chemical complementation, the concentrate was added to a $100 \mathrm{ml}$ of growing cultures of OGU1 at $7^{\text {th }} \mathrm{h}$ of incubation to introduce ca. $150 \mathrm{Units} / \mathrm{ml}$ and the incubation was continued. As another negative control, OGU1 broth concentrates were also prepared in the same way and added in the same volume to a parallel OGU1 culture.

\section{Protein extraction}

Bacilysin levels were routinely monitored in cultures used for protein extraction. To isolate cytosolic proteins, $15 \mathrm{ml}$ aliquots of $16 \mathrm{~h}$ cultures were centrifuged at $6,000 \mathrm{rpm}$ for $5 \mathrm{~min}$, after which the pellet was washed twice with cold TE buffer. After resuspending in lysozyme $(40 \mathrm{mg} / \mathrm{ml}$ in $0.04 \mathrm{M}$ TE buffer) and incubating for $1 \mathrm{~h}$ at $37^{\circ} \mathrm{C}$, the samples were centrifuged at 13,000 rpm for $10 \mathrm{~min}$ at RT. After adding $8 \mathrm{M}$ urea onto the pellet and vortexing at $4^{\circ} \mathrm{C}$, another centrifugation was made at 13,000 rpm for 15 min to collect the supernatant. Protein concentration determinations were made as in Ramagli and Rodrigez (1985), the concentrations were equalized for each sample and the resulting protein samples were stored at $-20^{\circ} \mathrm{C}$.

\section{DE}

For each strain, two independent biological samples were run, each with two technical replicates. A $50 \mu \mathrm{g}$ protein aliquot was mixed with SDS-PAGE sample buffer and protein separation was done in $12 \%$ acrylamide/bis-acrylamide gels (Bio-Rad Cell System) by applying $16 \mathrm{~mA} / \mathrm{gel}$, after which the proteins were stained with CCB (Neuhoff et al., 1988). Ten equidistant pieces were cut from each lane of $1 \mathrm{D}$ gel for the tryptic in-gel digestion and peptide elution for liquid chromatography-tandem mass spectrometry (nanoLC-MS/ MS).

\section{2-DE and image analysis}

For each strain, two independent biological samples were run, each with two technical replicates. Isoelectric focusing (IEF) was performed as described in Görg et al. (2004) using the linear IPG-strips: $17 \mathrm{~cm}$, pH 4-7, Bio-Rad; $18 \mathrm{~cm}$, GE Healthcare Immobiline DryStrip $\mathrm{pH} 4.5-5.5$, and $18 \mathrm{~cm}$, GE Healthcare Immobiline DryStrip pH 5.5-6.7, after rehydration and IEF, $12 \%$ acrylamide/bis-acrylamide gels were run for the second dimension on a Biorad Protean Xii electrophoresis system (Bio-Rad), applying approximately 25 $\mathrm{mA} / \mathrm{gel}$. After CCB staining and digitizing the gels using an HP scanner, the 2D image analysis software Delta2D version 3.3 (Decodon) was employed for the processing of gel images and gel-based relative quantitation of protein spots. Gels in each group (B. subtilis OGU1 and B. subtilis PY79) were used to generate a fused master gel image which contained all the spots coming from each replicate. By using the volume percentage ratios for each spot, a spot intensity showing at least a 2.5-fold difference between B. subtilis OGU1 and PY79 was selected for identification by MALDI-TOF/MS analysis. Standard deviations of the spot intensities from the replicates remained in the range of $20 \%$.

\section{MALDI-TOF/MS and NanoLC-MS/MS}

The MS analyses of the spots excised from 2DE gels and equidistant gel pieces from 1D gels were performed at the Institute of Microbiology, Ernst-Moritz-Arndt-University, as in Eymann et al. (2004). After destaining of spots, tryptic digestions and peptide elutions, MALDI-TOF/TOF ProteomeAnalyzer 4,700 (Applied Biosystems) was used for the peptide mass determination. Three most abundant peptides in each MS spectrum were chosen and the resulting sequence data were included in the database search. A linear trap quadrupole (LTQ) Oribtrap (Thermo Fisher Scientific) equipped with a nanoACQUITY UPLC (Waters) was employed for nanoLC-MS/MS analysis of the peptides eluted from $1 \mathrm{D}$ gels. Trap and elute mode was used to separate peptide 
mixture by LC system as described by Eymann et al. (2004). The mass spectrometric analysis started with a full survey scan in the Orbitrap (m/z 300-2000, resolution of 60,000$)$ followed by collision-induced dissociation and acquisition of MS/MS spectra of the five most abundant precursor ions in the LTQ. Precursors were dynamically excluded for $30 \mathrm{sec}$, and unassigned charge states as well as singly charged ions were rejected. For quantification of abundance differences, the relative spectral counts $\left(R_{s c}\right)$ were calculated for quantitation of the abundance differences of the proteins identified from the strains by using the formula provided by Old et al. $(2005):\left[\mathrm{R}_{\mathrm{sc}}=\log 2\left[\left(\mathrm{n}_{2}+\mathrm{f}\right) / \mathrm{n}_{1}+f\right)\right]+\log 2\left[\left(\mathrm{t}_{1}-\mathrm{n}_{1}+\mathrm{f}\right) /\left(\mathrm{t}_{2}-\mathrm{n}_{2}+f\right)\right]$ $\mathrm{R}_{\mathrm{SC}}$ is the $\log 2$ ratio of abundance between Samples 1 and $2 ; \mathrm{n}_{1}$ and $\mathrm{n}_{2}$ are spectral counts for the protein in Samples 1 and 2 , respectively; $t_{1}$ and $t_{2}$ are total numbers of spectra over all proteins in the two samples and $f$ is the correction factor. In the present study, the correction factor $f$ was set to 1.25 in calculations and the proteins with $\mathrm{R}_{\mathrm{sc}}$ values higher than 2.0 were selected as differentially expressed.

\section{Database search and bioinformatic analyses}

B. subtilis genome project web address (http://genolist.pasteur. $\mathrm{fr} /$ SubtiList/) was used to obtain the amino acid sequences of the proteins. Briefly, the database search was performed by using the SEQUEST software (Bioworks v.3.2, Thermo Electron) and the results were imported to Scaffold 2.02.01 (Proteome Software) for validation of MS/MS-based peptide and protein identifications. The data obtained from MALDITOF/MS measurement were analyzed by using "Peptide Mass Fingerprint (PMF)" and "MS/MS Ion Search" engines of MASCOT software (http://www.matrixscience.com/) against the $B$. subtilis PMF database. For protein identifications, the protein score values higher than 98 were accepted. Protein accession numbers of the identified spots which were included in the MASCOT output were searched in the SubtiList Web Server and Protein Knowledgebase (UniProtKB) (http:// www.uniprot.org/) for finding out the putative functions of

Table 1. Primer sets used for real-time quantitative PCR

\begin{tabular}{|c|c|c|}
\hline Gene & Sense primer $\left(5^{\prime}-3^{\prime}\right)$ & Antisense primer $\left(5^{\prime}-3^{\prime}\right)$ \\
\hline$r p o B$ & TGAACATCGGGCAGGTATTG & GTTTCCCAGACATCCTCTTCTC \\
\hline$d p a A$ & GGAACGATCATGCTGGCTAT & AACTTCTTGCCCCCACTTTT \\
\hline$d p a B$ & TTTTATTCCATTCGGGCAAG & GTGCATGAGTGCCTTTTCAA \\
\hline $\cot A$ & GCCGCTTCTTATCACAGACC & CCGGAACGATTGAAGGATTA \\
\hline$y t f J$ & CGAAAAGAAATCGGAAGACG & ATTCTGATGCCTGTCGATCC \\
\hline$y h c Q$ & TCAAAACAGGAAGCGAACCT & ATTTGTCGGCTGATGATGCT \\
\hline$y x b C$ & GAACTCGCTGTAAATCATCAATCC & GGTCAATGTCTCTGCGTTCT \\
\hline cheV & AGTTTGGCGTGGGTGAAA & CTTCTACATGCTGATGGGAGTG \\
\hline $\operatorname{res} D$ & TGAAGCGGGAACAGATGATT & GAGGTTTGGGATGCTCTTCT \\
\hline phoP & TTTGGAACGGTCAGGCTATG & GCATCACATCAAGCACAATCAA \\
\hline $\operatorname{deg} U$ & GCGGTTAAAGTAGTGGCTGA & TGTTGAGGGTGTGCAGAAA \\
\hline $\operatorname{deg} S$ & CAGAGGACGGATTCCAAGAAA & CAAGGGCCATCGGTCTTAAA \\
\hline gerE & CTCGTTCAAGATAAGACAACAAAGG & CACACCCAATTTCTGCATGG \\
\hline $\operatorname{cod} Y$ & TGAGGAGCTTGACGGAAATG & GAGTGCGTTCACAATAACAGAAC \\
\hline$a b r B$ & TGCCAAGTAACTGGTGAAGTT & GGATTTCGCTGATGATTTGCTC \\
\hline $\operatorname{ccp} A$ & TGGACGGCATCGTGTTTAT & GTGTTTCCTCCTGCTCTTCTAC \\
\hline$a b b A$ & ACGATATAGAGACAGGGACCA & CAAATCGAAATCGGTCGTATAGC \\
\hline spooA & AGTGATCGGCGTTGCTTAT & CCGTCTAGATGCGGCATAAT \\
\hline yugI & GCTGCTCAAGTAAGCGAAGA & TAAGGTCTTTGCGGTTGGAC \\
\hline$d n a K$ & ATTCAGGGCGGCGTTATC & TGTTGCGGTCGATCAGTTT \\
\hline$y c e E$ & GGCATCACAGTGACCATTCA & CTCCCAAATCGAAGCGAAGA \\
\hline$y t k L$ & ACCTTGCTTTCCTTCCGATT & TTCGATGACCGGGAATGTAT \\
\hline $\operatorname{luxS}$ & GAAGCCTGACACCATTCACA & GGCAGCCCATTGGAGAAATA \\
\hline albE & TCACTGATCССТTCTCСТАСТC & GAATCGCCTTTATCCTGTCTCTC \\
\hline ispa & AGCTTCCTGAGGGCATTAAA & GTCGCAGCCTGTGTCTAATA \\
\hline oppD & CTGCTGGAATTAGTCGGTATCC & GCAATGACAACCCTCTGTCT \\
\hline$d n a A$ & CGTCAAATCGCCATGTACTTATC & ATCACGTCCTCCAAACTCTTC \\
\hline $\operatorname{glm} S$ & GCTCGTGAATACCTGACTGTATC & CCTTCTGCCTGGATGTAAGAAA \\
\hline$g \ln A$ & GACCTCGGCTTCAGTGATTT & TCCGCCTTTGTCGTTTAGTT \\
\hline mals & GTTTTAGATGCGGGGACAAA & GCGCAACGTAGTCGTCAATA \\
\hline$b a c A$ & CTTCTACAAGGGCTGAACAGTAA & GCATGTGGGACGATGGTATATT \\
\hline$b a c B$ & CTGATGATGACTGTCGGAGATG & TCTTGGTCTGTGTCGTTTCTT \\
\hline bacC & ATGTGGTTGTGGCGGATATT & TCGTCTGTGATGTCCGTTTG \\
\hline$b a c D$ & CATAACAAGCCTGAGGAAGAGG & CGCCATCGGAGCAATGAATA \\
\hline$b a c E$ & GTCATGTCGTCCTTGGAATCA & CAGATCCGCCTAACAGAAAGAG \\
\hline$b a c F$ & GGGAATACGGAGTGACAATCAA & GATTCGGGACTAAAGCGATGT \\
\hline bacG & TGTCGGAAATCTGTGGAAAGAA & GGAGCAAGCTGGATGGAAATA \\
\hline
\end{tabular}


proteins. The functional classification of the proteins was according to the categories in the SubtiWiki database (Michna et al., 2016; Zhu and Stülke, 2018). PSORT web server (http://wolfpsort.hgc.jp) and the SignalP web server (http:// www.cbs.dtu.dk/services/SignalP/) were used for protein subcellular localization and signal peptide predictions, respectively.

\section{RNA extraction and RT-qPCR}

For total RNA extraction, PY79 and OGU1 overnight cultures were used to inoculate $100 \mathrm{ml}$ of fresh PA media without any antibiotics to an initial $\mathrm{OD}_{595}$ of 0.1 . IPTG induction was carried out by adding $1 \mathrm{mM}$ IPTG to OGU1 culture at $15^{\text {th }} \mathrm{h}$. All cultures including the IPTG induced one were harvested at $16^{\text {th }} \mathrm{h}$ and checked for bacilysin levels prior to RNA extraction. Total RNA isolation from $B$. subtilis PY79, OGU1, and IPTG induced OGU1 cells was performed with Nucleospin ${ }^{\circledR}$ RNA Kit (Macherey-Nagel GmbH \& Co) according to the manufacturer's instructions with minor modifications. These modifications were namely usage of $450 \mu \mathrm{l}$ of lysis buffer RA1 and $70 \%$ ethanol instead of $350 \mu \mathrm{l}$. The quality and the concentration of total RNA samples were measured with Nanodrop (BioDrop) spectrophotometrically at both 260 and $280 \mathrm{~nm}$. For the integrity of total RNA samples, two important criteria - RIN (RNA integrity number) and 23S/16S rRNA ratio - were checked with Bioanalyzer 2100 (Agilent). Total RNA samples were kept at $-80^{\circ} \mathrm{C}$ until further usage.

cDNA synthesis from total RNA samples was achieved with usage of iScript ${ }^{\mathrm{TM}} \mathrm{cDNA}$ Synthesis Kit (Bio-Rad Laboratories) following the manufacturer's instructions. In this reaction, $1 \mu \mathrm{g}$ of total RNA was converted into total volume of $20 \mu \mathrm{l}$ cDNA with mixture of oligo(dT) and random hexamer primers. Synthesized cDNAs were used as the template in RTqPCR reactions which were performed in $0.2 \mathrm{ml} \mathrm{8}$-Tube PCR Strips with caps (Bio-Rad Laboratories). RT-qPCR reactions were carried out with SsoAdvanced ${ }^{\mathrm{TM}}$ Universal SYBR $^{\circledR}$ Green Supermix (Bio-Rad Laboratories) following the manufacturer's instructions and the fluorescent signal detection was done with CFX Connect ${ }^{\mathrm{TM}}$ Real-Time PCR Detection System (Bio-Rad Laboratories). Primer sets are listed in Table 1.

For the analysis of every gene, two independent qPCR runs were performed and each run contained three biological and two technical replicates of both PY79 and OGU1. Each run also included a no template control sample having nuclease free water instead of cDNA. To observe possible contaminant PCR products, melting curve analyses were performed for each run covering the temperature range of $40-95^{\circ} \mathrm{C}$. Fold changes were calculated with $2^{-\triangle \Delta C T}$ method improved with efficiency correction (Rao et al., 2013) and rpoB gene that encodes for RNA polymerase beta subunit in $B$. subtilis was selected as the internal control gene. For statistical analysis, Student's t-test was carried out with GraphPad Prism 7 (Graphpad Software) and statistical significance reported as ns (no significance, $p>0.05),{ }^{*}(p<0.05),{ }^{* *}(p<$ $0.01)$, and ${ }^{* *}(p<0.001)$.

\section{Characterization of colony morphologies}

Colony morphologies were visualized on $1 \mu \mathrm{l}$ of initial cul- ture spotted DSM plates incubated for 18 days at $30^{\circ} \mathrm{C}$. Epson Perfection V750 Pro scanner was used to obtain the images.

\section{Mature spore purification}

The procedure used was adopted from Nicholson and Setlow (1990). DSM-grown B. subtilis cells were harvested after $48 \mathrm{~h}$ incubation by centrifugation at $10,000 \times g$, for $10 \mathrm{~min}$. After purifying spores by washing twice with ice-cold $\mathrm{dH}_{2} \mathrm{O}$ and treatment with lysozyme $(0.1 \mathrm{mg} / \mathrm{ml})$ for $10 \mathrm{~min}$ at $37^{\circ} \mathrm{C}$, spores were collected after re-washing several times and resuspending in ice-cold $\mathrm{dH}_{2} \mathrm{O}$ and kept in dark at $-20^{\circ} \mathrm{C}$.

\section{Determination of sporulation efficiency and spore resistance}

After culturing in DSM at $37^{\circ} \mathrm{C}$ for $48 \mathrm{~h}$, the aliquots taken from the cultures were serially diluted in saline solution and plated on LA before and after heat treatment at $80^{\circ} \mathrm{C}$ for 30 min. Sporulation efficiency was expressed as the number of sporulated cells over total CFU/ml.

In order to determine heat resistance profiles, viable counts were made for the purified spores heated at $80^{\circ} \mathrm{C}$ for $30 \mathrm{~min}$. Chloroform and lysozyme resistance of purified spores were determined as in Nicholson and Setlow (1990). Survival ratios were expressed as the ratio of $\mathrm{CFU} / \mathrm{ml}$ before and after treatment.

\section{Dipicolinic acid (DPA) content of spores}

DPA content of purified spores was analyzed as described by Nicholson and Setlow (1990) after diluting, pelleting and resuspending them in ice-cold $\mathrm{dH}_{2} \mathrm{O}$.

\section{Spore germination}

Germination assay with purified spores was as in Nicholson and Setlow (1990). The $\mathrm{OD}_{585}$ readings were normalized according to the first reading $\left(t_{0}\right)$ and expressed as averages with \pm standard deviations. As proposed by Atluri et al. (2006), a $60 \%$ decrease in relative $\mathrm{OD}_{585}$ was accepted to correspond to germination of the whole spore population.

\section{Extraction of coat proteins and small acid soluble proteins (SASPs) from spores}

The procedure originally described by Takamatsu et al. (2000) was used for solubilization of the majority of spore coat proteins. Briefly, harvested mature spores were washed, suspended in lysozyme buffer, re-washed and solubilized in loading buffer. The resulting samples were subsequently analyzed by SDS-PAGE (15\% acrylamide/bis-acrylamide; Bio-Rad Cell System) by applying $20 \mathrm{~mA} / g e l$, after which the proteins were stained with CCB (Neuhoff et al., 1988). After excision and destaining of selected bands, tryptic digestions and peptide elutions, the MS analyses were performed at the HUNITECH Center of Hacettepe University, Ankara, using an Ultraflextreme MALDI-TOF (Bruker Daltonics). MS/MSbased peptide and protein identifications were made as described above. SASPs were extracted from the purified spores by using a dental amalgamator for dry rupture of spores followed by $<5,000 \mathrm{Da}$ cut off dialysis (Nicholson and Setlow, 1990). The lyophilized material was dissolved in $8 \mathrm{M}$ urea before PAGE at low $\mathrm{pH}$. 


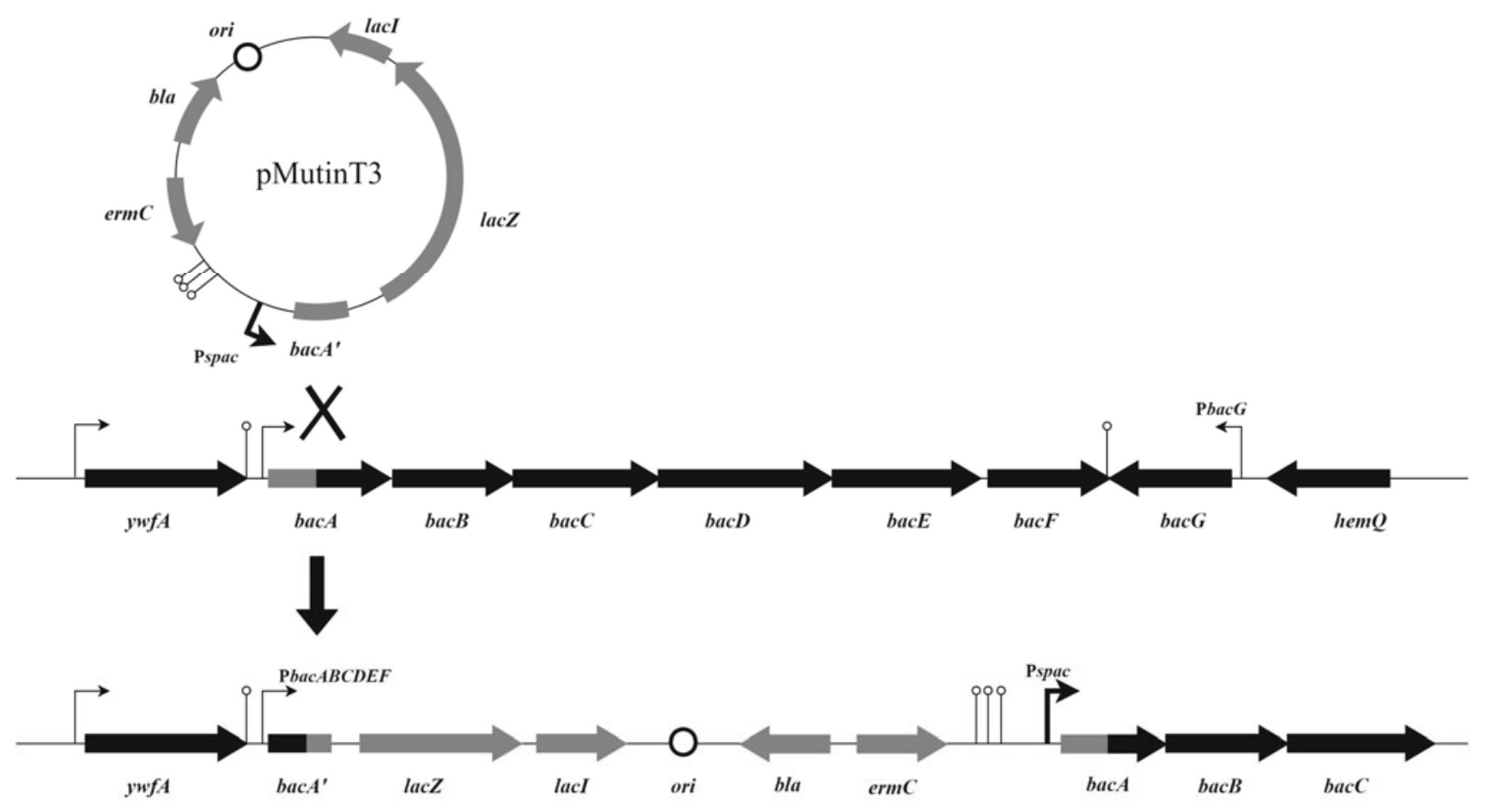

Fig. 2. The diagram of $b a c A$-targeted pMutin T3 insertion into OGU1 genome. The resulting genomic organization (bacA'::lacZ::erm::bacABCDEF and the flanking regions) contains $\mathrm{P}_{b a c}, 5^{\prime}$-region of $b a c A\left(b a c A^{\prime}\right)$, pMutin $\mathrm{T} 3$ followed by the whole bac operon under $\mathrm{P}_{\text {spac }}$, ending up with an IPTG inducible bac operon.

(A) 1

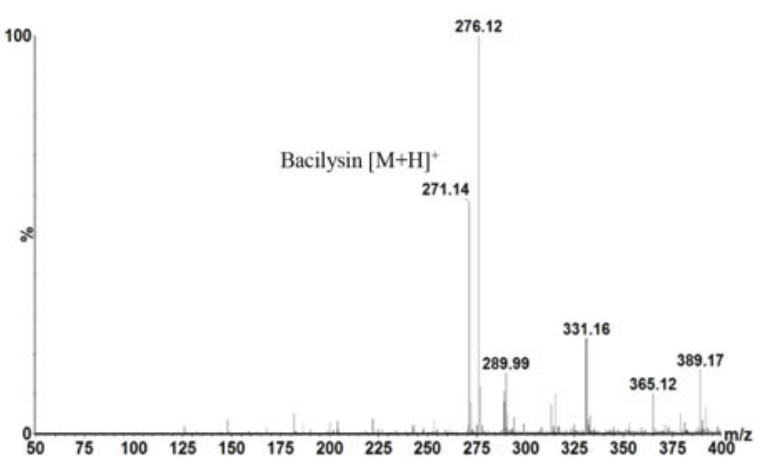

(B)

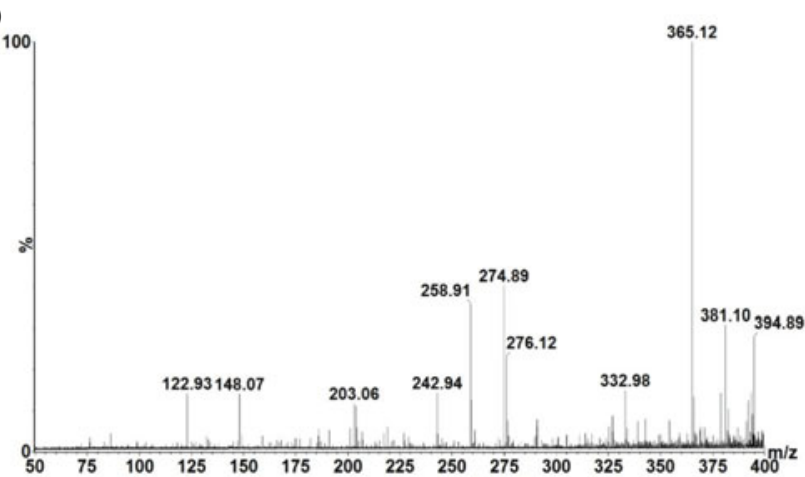

Fig. 3. UPLC-mass spectrum of culture extracts of B. subtilis PY79 (A), OGU1 (B), and OGU1 treated with IPTG (C). Culture extracts were analysed with UPLC-MS at positive detection mode. Bacilysin $[\mathrm{M}+\mathrm{H}]^{+}$at $\mathrm{m} / \mathrm{z}$ 271.1 was only detected in culture extract of PY79 which was not detected in OGU1 and OGU1 treated with IPTG.

(C)

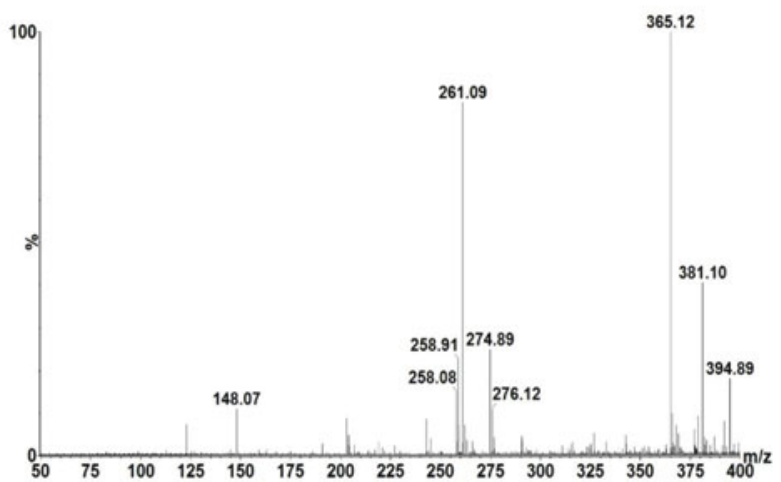




\section{Biofilm formation}

Microtitre plate assay of biofilm formation was performed according to the protocol described by Hamon and Lazazzera (2001).

\section{Results and Discussion}

Supplementary data Table S1 shows whole genome resequencing (WGRS) of OGU1 (GenBank accession no. QLNM00000000.1) and its parental strain PY79 of our laboratory (GenBank accession no. WOWX00000000) in reference to BGSC-deposited PY79 (GenBank accession no. CP006881.1). Accordingly, OGU1 has a total of 5 SNPs and 1 deletion and its parental PY79 has 3 SNPs and 5 indels. Three SNPs (in two putative deacetylase genes, $y l x Y$ and $y x k H$, and the noncoding region between $y w c C$ gene and 5'UTR of $s l r A$ ) and one deletion (at $\mathrm{K}^{6}$ of $s w r A A / 1$ [swarming motility protein; control of DegU activity]) are common to both our PY79 and OGU1 (Supplementary data Table S1). To be more specific, the SNP at the non-coding region is located at a site to which no transcription factor is theoretically bound. The other SNPs result in missense mutations in $y l x Y$ and $y x k H$ at $\mathrm{P}^{264}$ to $\mathrm{K}^{264}$ and $\mathrm{V}^{168}$ to $\mathrm{M}^{168}$, respectively while the common deletion results in a frameshift mutation. In addition, OGU1 and its parental PY79 have some unique alterations as well. The parental strain has four indels, two of them being present in fruA (fructose-specific PTS), one in $b m r U$ (multidrug resistance protein), and another one in 16S RNA coding $r r n B$, the former two causing alterations in protein structure. On the other hand, OGU1 has only two distinct SNPs, which are located in the coding region of prkA (putative serine protein kinase; control of SigK-dependent gene expression) and 16S RNA coding rrnE. The SNP in prkA results in a silent mutation $\left(R^{525} R\right)$.

As deduced from the analysis of the whole sequence of $b a c$ operon and its flanking regions in OGU1, pMutin T3 containing $5^{\prime}$-region of $b a c A$ (designated as $b a c A^{\prime}$ ) has been inserted in between $\mathrm{P}_{b a c}$ and the remaining $3^{\prime}$-region of $b a c A$. Thus, an intact $b a c A$ gene and the rest of bac operon under $\mathrm{P}_{\text {spac }}$ were obtained in OGU1. Accordingly, the resulting genomic organization (bacA' ::lacZ::erm::bacABCDEF) has constituted an IPTG-inducible operon (Fig. 2). The sequence of bac $A B C$ - pMutin T3 - bac $A^{\prime}-y w f A$ genomic region in OGU1 is presented as Supplementary Data 1 . The OGU1 cultures were induced with IPTG at different stages of growth and for different time durations. The samples were then collected at time intervals for determination of bacilysin activity by paper disc-agar diffusion assay. Culture fluids of IPTG-induced and uninduced OGU1 cultures gave no zone of inhibition in bioassays while the expected bioactivities were obtained from PY79 culture fluids in all trials (data not shown). UPLC-MS analysis was performed to confirm the lack of bacilysin production upon IPTG induction of OGU1. The peak with an $\mathrm{m} / z$ of 271.1 corresponding to the mass of bacilysin $(\mathrm{M}+\mathrm{H})^{+}$(Walker and Abraham, 1970; Yazgan et al., 2001) was absent from the culture fluid extracts of IPTG-induced and uninduced OGU1, but present in that of PY79 as the positive control (Fig. 3).

OGU1 cells had a sporulation efficiency of $90 \%$, which was almost equal to that of PY79. Purified mature spores of this strain were as heat-resistant as those of PY79, but more sensitive to lysozyme and chloroform (Table 3 ). When the yellowish-brown pigmentation of spores was assessed, the less pigmented phenotype of OGU1 colonies was evident starting from the day 10 (Fig. 4A). SDS-PAGE of spore coat proteins revealed at least 8 underrepresented and/or missing bands in OGU1 as compared to PY79 (Fig. 4B). As to the germination response, OGU1 spores displayed a germination delay of $25 \mathrm{~min}$ in rich $(2 \mathrm{xYT})$ medium and $30 \mathrm{~min}$ in minimal (SMM) medium with respect to PY79 spores (Fig. $4 \mathrm{C})$. There were no differences in DPA level (16.139 \pm 1.438 and $15.828 \pm 1.758 \mu \mathrm{g}$ per OD600, for OGU1 and PY79, respectively) and alpha/beta- and gamma-type SASPs of spores (data not shown) between two strains. On the other hand, the strains formed no biofilms, and the swarming behavior of the strains was almost the same (data not shown). When the parallel growing cultures of OGU1 were supplemented with broth concentrates of PY79 and OGU1, all of the abovementioned deficiencies were almost completely cured in cultures that received the former concentrate, but not the latter (Table 3 and Fig. 4). This finding proves the ability of bacilysin to reverse bac operon silencing-induced phenotypic changes in B. subtilis. Bacilysin concentrate addition did not harm or alter the growth of OGU1 (Fig. 5A) and the activity of externally introduced bacilysin declined rapidly as it could not be compensated by newly synthesized bacilysin (Fig. 5B). Among the spore coat proteins recovered upon bacilysin addition to OGU1 culture, the identity of 4 could be determined as YaaH, SleB, LipC, and CotS (Fig. 4B). Except for CotS, all these proteins were also identified to be downregulated in OGU1 by our proteomic analyses (Table 2). CotS, on the other hand, is formed simultaneously with CotSA during T5 to T7 of sporulation and responsible for assembly of CotSA (Takamatsu et al., 1999), the latter being another underrepresented spore coat proteins we detected.

In PA cultures of PY79, bacilysin activity peaks at the $16^{\text {th }} \mathrm{h}$ of incubation, upon entry into stationary phase and decreases abruptly during late stationary phase (Özcengiz et al., 1990; Köroğlu et al., 2011). For this reason, the cells were collected at $16^{\text {th }} \mathrm{h}$ of incubation to check for bacilysin, and to prepare samples for proteomic analyses and RT-qPCR experiments. Since B. subtilis cytosolic proteome analysis in one single $2-\mathrm{DE}$ gel with a $\mathrm{pH}$ range of $4-7$ is known to cover two third of all proteins (Eymann et al., 2002), we also employed two narrow $\mathrm{pH}$ ranges of 5.5-6.7 and 4.5-5.5 in order to resolve the regions of spot crowding in this range. A total of 1986 spots were detected by dual channel 2-DE imaging in three different $\mathrm{pI}$ ranges of $4.0-7.0,4.5-5.5$, and 5.5-6.7 with the separation of 1100,243 , and 643 protein spots, respectively (Supplementary data Fig. S1A, B, and C). Over 250 protein spots were differentially expressed between PY79 and OGU1. One hundred and fifty-nine differentially expressed proteins could be identified which corresponded to 121 distinct ORFs (Supplementary data Table S2). Of these, the levels of 63 were found to be decreased, 33 were expressed more abundantly, 20 were found to be absent in bacilysin-nonproducer OGU1 and 1 protein spot was detected only in this strain. Fifteen proteins appeared in multiple spots, suggesting posttranslational charge and/or mass modifications although ar- 
(A)

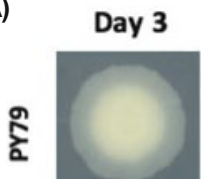

\section{Day 5}
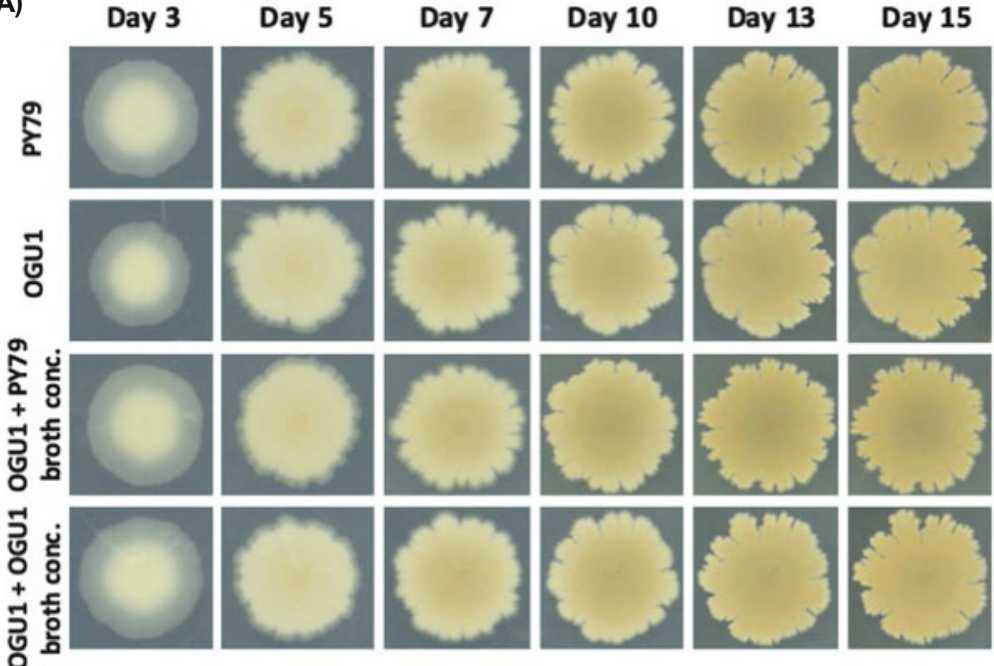

Day 18
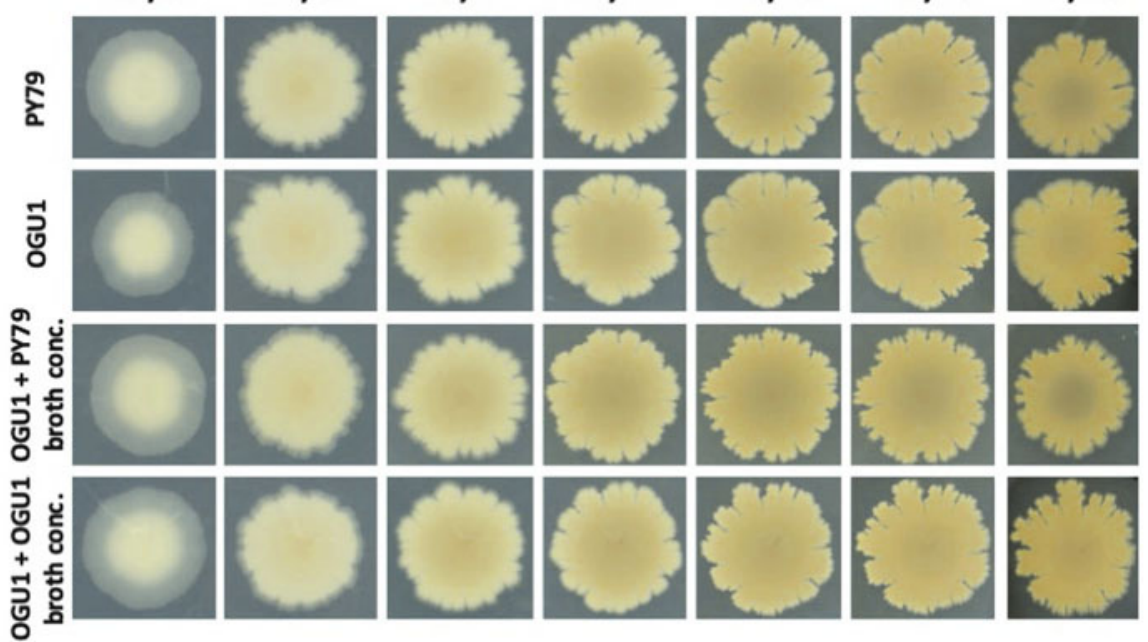

Fig. 4. Morphological effects of bacilysin silencing and its chemical complementation in OGU1. All tests included the cultures of OGU1 supplemented (OGU1 + PY79) and non-supplemented with bacilysin broth concentrate (OGU1 only; negative control) as well as PY79 itself (positive control) and OGU1 supplemented with its own broth concentrate (OGU1 + OGU1; further negative control). The cultures were grown for $16 \mathrm{~h}$ in PA medium, after which the morphology of the diluted spots was visualized on DSM plates at intervals for 18 days (A). Germination responses of spores purified from $48 \mathrm{~h}$ DSM broth cultures in rich $(2 \mathrm{xYT})$ and minimal (SMM) medium (B). SDS-PAGE analysis of coat proteins isolated from spores harvested and purified after $48 \mathrm{~h}$ incubation. Arrows point to the protein bands missing or underrepresented in OGU1 and restored upon chemical complementation (C).

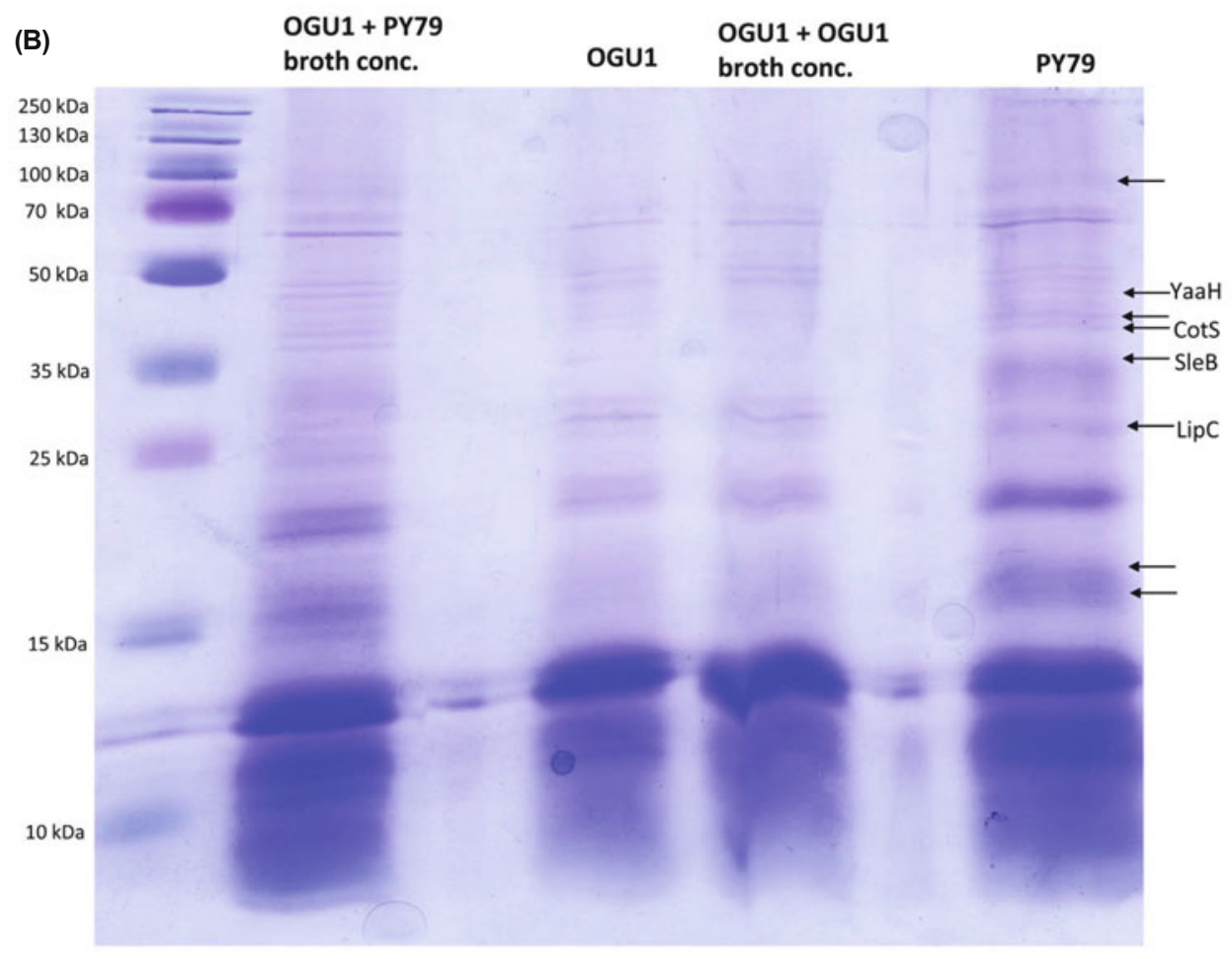

(C)

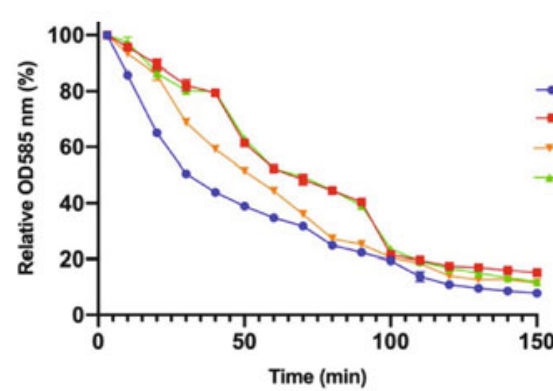

SMM

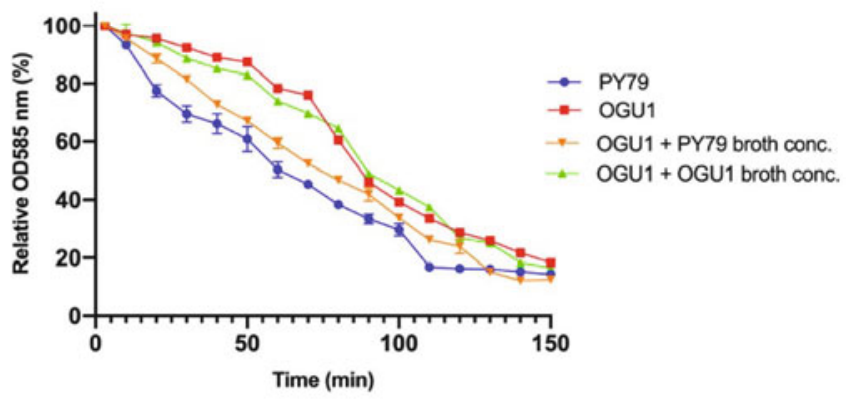



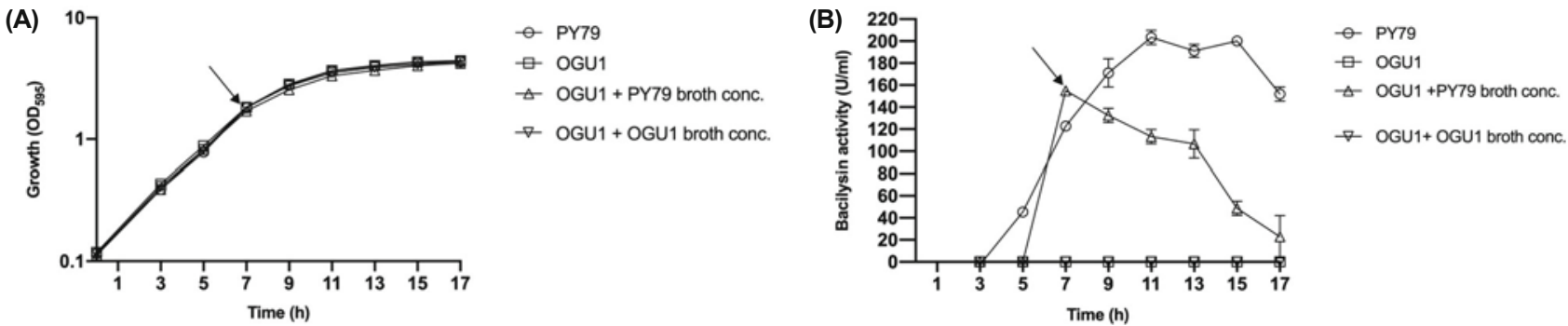

Fig. 5. Growth and bacilysin titers in OGU1 cultures supplemented with broth concentrates from PY79 and OGU1. Broth concentrates of PY79 and OGU1 obtained from $16 \mathrm{~h}$ PA cultures were added to parallel PA cultures of OGU1 at the time indicated by arrow. Growth (A) and bacilysin titers (B) of these cultures were next monitored. Parallel cultures of PY79 and OGU1 were also included as positive and negative controls.

tificial chemical modifications/unintended protein degradation occurring during protein preparation cannot be ruled out. In addition, 4 distinct proteins (\#31, \#33, \#41, and \#74) displayed opposing ratios either in the same or a different
pI range. This might be due to protein comigration and partial comigration that can occur in $2 \mathrm{D}$ gels, imposing a challenge in quantification. NanoLC-MS/MS led to the identification of 1282 proteins from cytosolic proteome of PY79

Table 2. Significantly underrepresented proteins in OGU1 as the members of sporulation $\sigma$ regulons in B. subtilis

\begin{tabular}{|c|c|c|c|}
\hline Regulon* & Protein & Product/Function & Approach $^{* *}$ \\
\hline \multirow{11}{*}{ SigE } & AsnO & Asparagine synthase (glutamine-hydrolysing)/ biosynthesis of asparagine & NanoLC \\
\hline & GerQ (YwdL) & Spore coat protein necessary for the proper localization of CwlJ/spore germination & $2 \mathrm{DE}$ \\
\hline & SodF & Superoxide dismutase/ detoxification of oxygen radicals & NanoLC \\
\hline & SpoVR & Unknown/ involved in spore cortex synthesis & NanoLC \\
\hline & $\mathrm{SpsB}^{\mathrm{c}, \mathrm{g}, \mathrm{m}}$ & Unknown/ spore coat polysaccharide synthesis & NanoLC \\
\hline & Sps $J^{\mathrm{c}, \mathrm{g}, \mathrm{m}}$ & dTDP -glucose-4,6-dehydratase/ rhamnose biosynthesis, spore coat polysaccharide synthesis & NanoLC \\
\hline & $\mathrm{SpsK}^{\mathrm{c}, \mathrm{g}, \mathrm{m}}$ & dTDP -4-dehydrorhamnose reductase/rhamnose biosynthesis, spore coat polysaccharide synthesis & NanoLC \\
\hline & $\mathrm{YheC}^{\mathrm{c}, \mathrm{j}}$ & Unknown/ ATP-binding spore coat protein & NanoLC \\
\hline & YodQ & Putative deacylase/ unknown & NanoLC \\
\hline & $\mathrm{CtpB}^{\mathrm{e}}$ & Carboxy-terminal processing serine protease, cleaves SpoIVFA/ processing of pro-SigK; control of SigK activation & NanoLC \\
\hline & $\mathrm{YaaH}^{\mathrm{b}, \mathrm{j}}$ & $\mathrm{N}$-acetylglucosaminidase/ survival of ethanol stress, protection of the spore & $2 \mathrm{DE}$ \\
\hline \multirow{3}{*}{ SigF } & $\mathrm{Gpr}^{\mathrm{d}, e, \mathrm{k}}$ & Germination protease/ degradation of SASPs & NanoLC \\
\hline & YtfJ & Unknown; germination & $2 \mathrm{DE}$ \\
\hline & Kat $A^{r}$ & Major catalase in spores; detoxification of hydrogen peroxide & NanoLC \\
\hline \multirow{5}{*}{ SigG } & SleB & Spore cortex lytic enzyme/ degradation of spore cortex, germination & NanoLC \\
\hline & TepA ${ }^{\mathrm{k}}$ & Orphan ClpP-like germination protease/degradation of SASP & NanoLC \\
\hline & YhcQ & Unknown & $2 \mathrm{DE}$ \\
\hline & YpeB & Germination protein/ essential for SleB assembly in spores & NanoLC \\
\hline & $\mathrm{YvaB}^{\mathrm{p}}$ & Azoreductase/ sporulation protein; resistance to 2-methylhydroquinone & $2 \mathrm{DE}$ \\
\hline \multirow{3}{*}{$\mathrm{SigH}$} & GalM (YoxA) & Aldolase-1-epimerase (mutarotase)/ unknown & $2 \mathrm{DE}$ \\
\hline & $\mathrm{MinC}^{\mathrm{a}, \mathrm{f}, \mathrm{h}, \mathrm{i}, \mathrm{l}}$ & Cell-division inhibitor (septum placement)/ destabilizes $\mathrm{Z}$ ring placement & $2 \mathrm{DE}$ \\
\hline & $\operatorname{MinD}^{\mathrm{a}, \mathrm{f}, \mathrm{i}, \mathrm{l}}$ & Septum placement/ cell division inhibitor & $2 \mathrm{DE}$ \\
\hline \multirow{13}{*}{ SigK } & $\mathrm{CgeA}^{\mathrm{m}, \mathrm{n}}$ & Spore crust protein/maturation of the outermost layer of the spore & NanoLC \\
\hline & $\operatorname{Cot} \mathrm{A}^{\mathrm{m}}$ & Laccase, bilirubin oxidase, spore coat protein (outer)/ resistance of the spore & 2DE, NanoLC \\
\hline & $\operatorname{CotE}^{c, m}$ & Outer spore coat morphogenetic protein/ controls the assembly of the outer spore coat & NanoLC \\
\hline & CotI & Spore coat protein/ spore envelope & NanoLC \\
\hline & $\operatorname{CotSA}^{\mathrm{m}}$ & Spore coat protein/ resistance of the spore & NanoLC \\
\hline & $\operatorname{Cot} \mathrm{U}^{\mathrm{m}, \mathrm{n}}$ & Spore coat protein/ resistance of the spore & NanoLC \\
\hline & CwlC & $\mathrm{N}$-acetylmuramoyl-L-alanine amidase/ mother cell lysis & NanoLC \\
\hline & $\mathrm{LipC}^{\mathrm{g}, \mathrm{m}, \mathrm{n}, \mathrm{o}, \mathrm{s}}$ & Spore coat phospholipase B/ spore germination & NanoLC \\
\hline & $\mathrm{OxdD}^{\mathrm{m}}$ & Oxalate decarboxylase/ inner spore coat protein; protection of the spore & NanoLC \\
\hline & DpaA (SpoVFA) & Dipicolinate synthase (subunit A)/ dipicolic acid production & $2 \mathrm{DE}$ \\
\hline & DpaB (SpoVFB) & Dipicolinate synthase (subunit B)/ dipicolic acid production & NanoLC \\
\hline & $\mathrm{YfnG}^{\mathrm{c}, \mathrm{m}}$ & Similar to CDP-glucose 4, 6-dehydratase/ unknown & NanoLC \\
\hline & YitD $^{c}$ & Unknown & NanoLC \\
\hline
\end{tabular}

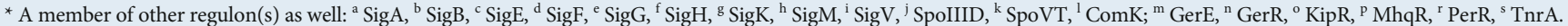

${ }^{* *}$ Identified by 2DE, 2-DE MALDI-TOF/MS; NanoLC, NanoLC-MS/MS 
Table 3. Heat, chloroform, and lysozyme resistance of spores purified from DSM cultures of PY79 and OGU1 after $48 \mathrm{~h}$ incubation

\begin{tabular}{cccc}
\hline Strain & Heat resistance & Chloroform resistance & Lysozyme resistance \\
\hline PY79 & $0.88 \pm 0.03$ & $0.47 \pm 0.03$ & $0.83 \pm 0.08$ \\
OGU1 & $0.91 \pm 0.04$ & $0.25 \pm 0.03$ & $0.49 \pm 0.11$ \\
OGU1 + OGU1 broth conc. & $0.89 \pm 0.05$ & $0.26 \pm 0.02$ & $0.53 \pm 0.08$ \\
OGU1 + PY79 broth conc. & $0.92 \pm 0.06$ & $0.44 \pm 0.03$ & $0.78 \pm 0.15$ \\
\hline
\end{tabular}

and OGU1. Seventy six of these proteins were differentially expressed in OGU1 by comparing the spectral counts of the samples, with 50 proteins absent, 7 underrepresented and 19 found only in OGU1 (Supplementary data Table S3). Indeed, there were only a few differentially expressed proteins common to both proteomic approaches, including the enzymes of bac operon, CotA, DegU, GlmS, MalS, SpoVF, YhcQ, YtfJ, and YtkL. NanoLC-MS/MS could actually detect many of the proteins identified by 2DE approach, but the high criteria employed to quantitate the relative spectral counts resulted in a large subtraction from the final list.

According to the relative functional distributions of differentially expressed proteins identified by both 2-DE and nanoLC approaches (Fig. 6A and B), "Metabolism" and "Life- styles" were the two top-level functional categories according to the categories in SubtiWiki database. The subcategory "Sporulation and Germination" under the category "Lifestyles" constituted as high as $58 \%$ of all missing and downregulated proteins of OGU1 strain identified by nanoLCMS/MS. The present study identified 35 underrepresented sporulation and germination proteins in OGU1, which belong to 5 sporulation sigma regulons (Table 2). Of these regulons, the mother cell compartment-specific $\sigma \mathrm{E}$ and $\sigma \mathrm{K}$ harbored the majority of these proteins. It is noteworthy that the total percentage of the subcategory "Unknown functions" was higher among the upregulated proteins than the downregulated ones, in both proteomic approaches.

In order to confirm the alterations in abundance (over- or
(A)
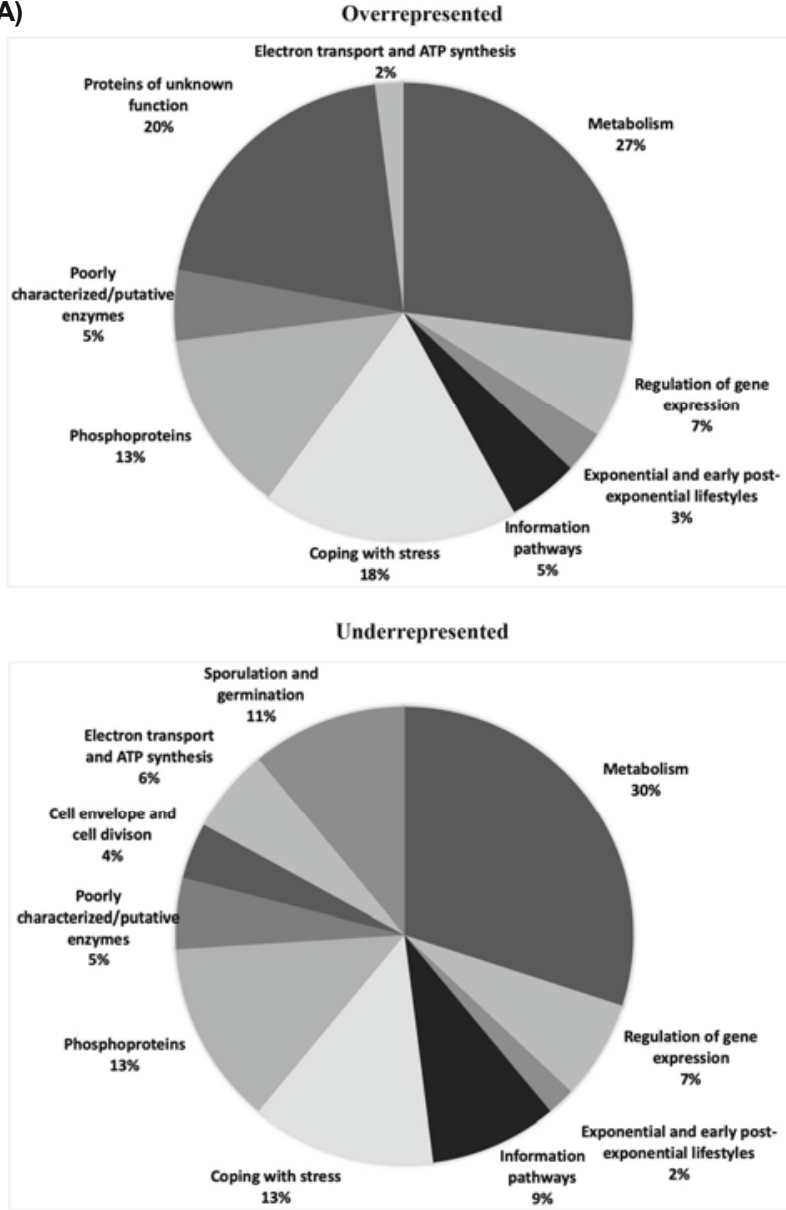

(B)
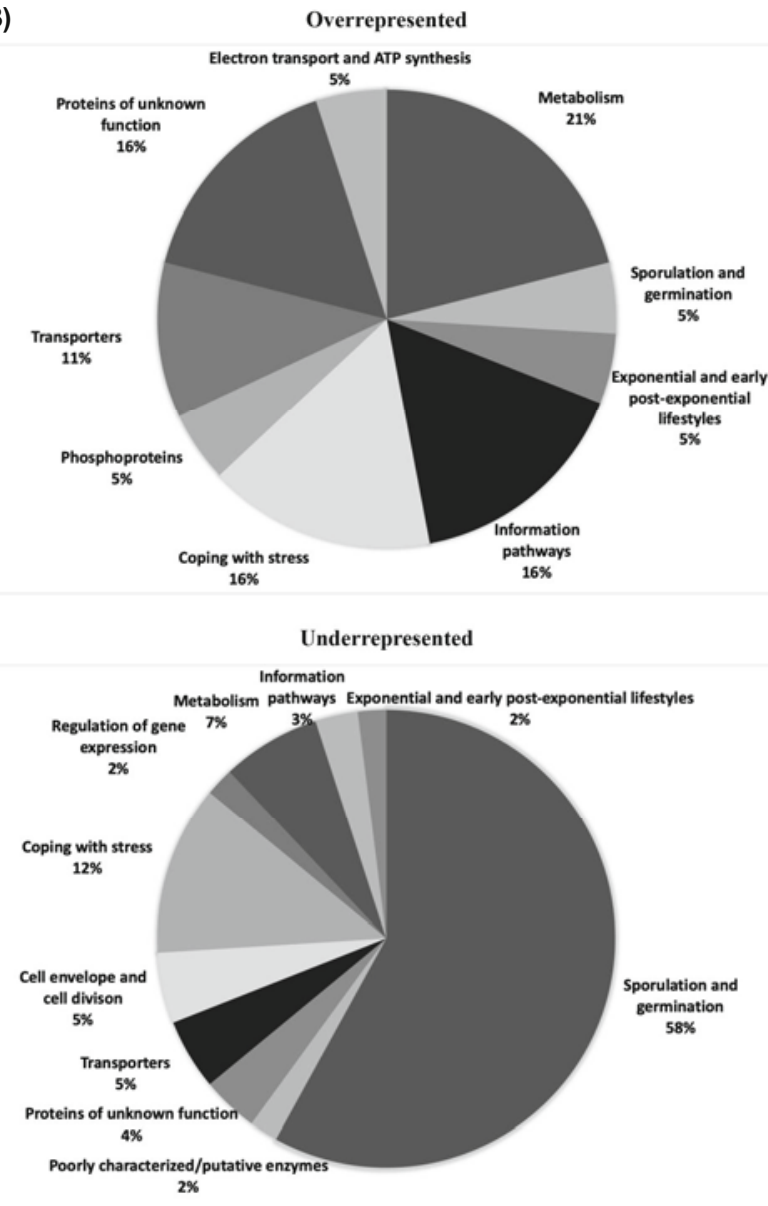

Fig. 6. Differentially expressed proteins in OGU1 with respect to their functional classes. Distribution of overrepresented (above charts) and underrepresented (below charts) proteins to major functional classes of cellular physiology in bacilysin non-producer OGU1 as determined by 2-DE MALDI-TOF/MS (A) and nanoLC-MS/MS (B) approaches. 
under-representation) of each protein, the genes coding for selected proteins (a total of 36) were next subjected to quantitative transcript analysis. Majority of these genes were selected as indicated by our proteomic data, and 9 of them (phoP, degS, gerE, codY, abrB, ccpA, abbA, spo0A, and dnaA) that could not be identified by the present proteome work were also included because of their significant global regulatory roles in cellular physiology, sporulation in particular, and/or their interaction with master regulators. The results expressed in fold change were tabulated separately with respect to the functions of the genes; "sporulation and germination" ( $d p a A, d p a B, \cot A, y t f f, y h c Q$, and $y x b C)$, "two-component systems" (cheV, resD, phoP, $\operatorname{deg} U$, and $\operatorname{degS}$ ), "global regulators" (gerE, $\operatorname{cod} Y, a b r B, c c p A, a b b A$, and $s p o 0 A$ ), "stress response" (yugI, dnaK, yceE, and $y t k L)$, "bacilysin biosynthesis" (bacA, bacB, bacC, bacD, bacE, bacF, and the monocistronic gene bacG), and "others" (luxS, albE, ispA, oppD, $d n a A, g \operatorname{lm} S, g \ln A$, and malS), as shown in Fig. 7A-F. No contaminant PCR products were observed according to melting curve analyses. Comparative RT-qPCR analysis between OGU1 and PY79 for these genes generally indicated a good correlation between transcript levels and proteomic data. Particularly, the transcripts of bac operon genes of uninduced OGU1 were 2- to 4-fold less abundant with respect to PY79 (Fig. 7E), consistent with our nanoLC-MS/MS data wherein the levels of corresponding proteins displayed 3to 5.5-fold decrease (Supplementary data Table S3). Except for monocistronic $b a c G$, IPTG induction provided 3- to 7 -fold increment in bac transcription. Thus, the lack of bacilysin in IPTG-induced OGU1 cultures is quite intriguing and deserves further investigation.
Combining the data obtained from the whole proteomics survey, the differentially expressed proteins are discussed with respect to their cellular functions:

\section{Proteins of sporulation and germination}

In all spore-forming bacteria, the network of cellular development and differentiation shows a well-conserved and strictly regulated hierarchical organization. In this, the mother cell and forespore compartment- and sporulation stage-dependent sigma factors and the master regulator Spo0A are sequentially activated (de Hoon et al., 2010). In the present study, the majority of underrepresented sporulation and germination proteins in OGU1 belonged to $\sigma \mathrm{E}$ and $\sigma \mathrm{K}$ regulons. While the former plays a decisive role in spore morphogenesis, the latter is activated after the completion of engulfment and directs the expression of genes required for synthesis of the spore cortex and coat proteins as well as those required for spore germination and mother-cell lysis (Steil et al., 2005). GerE, as a component of $\sigma \mathrm{K}$ regulon and the final regulator turning on the expression of last genes in mother cell compartment according to the hierarchical programme of sporulation, harboured 9 of the differentially expressed protein genes of $\sigma \mathrm{E}$ and $\sigma \mathrm{K}$ regulons in its own regulon. As a small regulatory protein $(8.43 \mathrm{kDa})$ with a high pI value (9.64), GerE was not detected in our proteomics work. Nonetheless, RT-qPCR analysis revealed 3.2-fold downregulation of its gene in OGU1 compared to PY79 (Fig. 7C).

Of about 70 proteins identified in the spore coat, the coat morphogenetic proteins that organize the assembly of different subsets of coat proteins include $\mathrm{CotE}, \mathrm{CotH}, \mathrm{CotO}$,
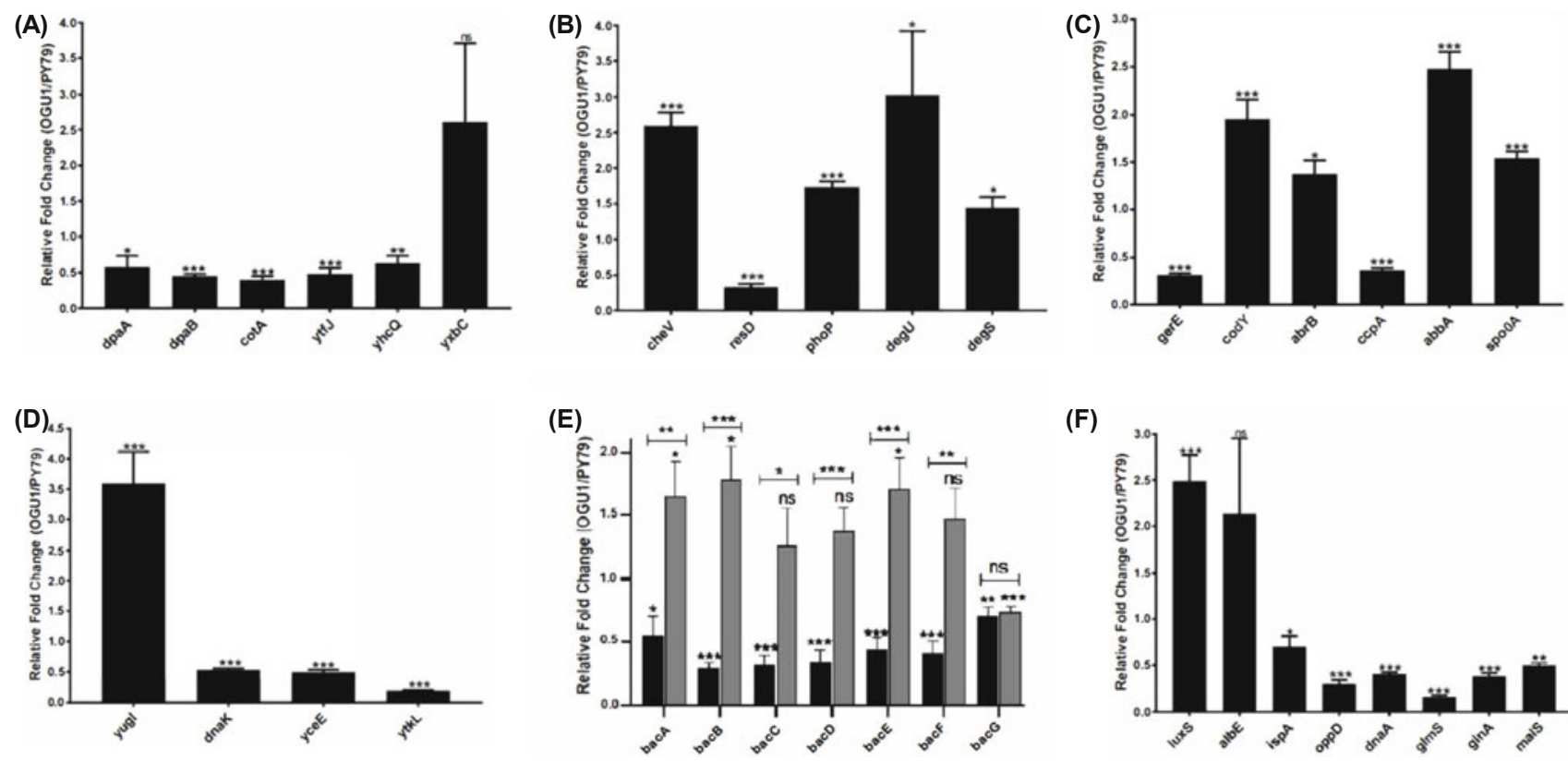

(F)

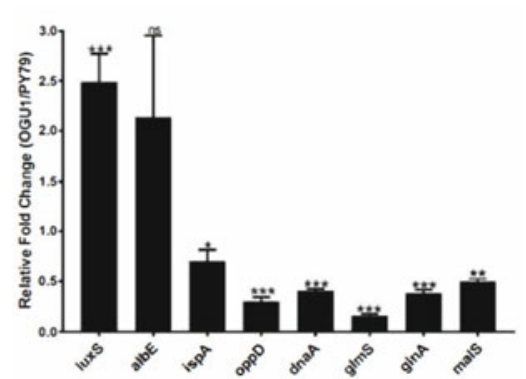

Fig. 7. RT qPCR analysis for the genes corresponding to selected differentially expressed proteins. Analysis by RT qPCR of the transcripts of the genes encoding selected proteins, which are differentially expressed in bacilysin-negative OGU1 and grouped with respect to their functions: "sporulation and germination" (A), "two-component systems" (B), "global regulators" (C), "stress response" (D), "bacilysin biosynthesis" (E) and "others" (F). In (E), bacilysin biosynthetic genes included those of $b a c$ operon $(b a c A B C D E F)$ as well as the monocistronic gene bacG. The gray bars show the relative transcript levels upon $1 \mathrm{~h} \mathrm{IPTG}$ induction at $15^{\text {th }} \mathrm{h}$, and the dark bars with no IPTG. The significance levels are represented as ns (no significance, $\left.\mathrm{p}>0.05\right),{ }^{*}(\mathrm{p}<0.05),{ }^{* *}(\mathrm{p}<0.01)$, and *** $(\mathrm{p}<0.001)$. Error bars represent standard error of the mean. 
SafA, and SpoVID since the loss of any of them would drastically interfere with overall coat architecture (Zheng et al., 1988; Plomp et al., 2014). Our study revealed the absence of many coat proteins, namely CgeA, CotA, CotB, CotI, CotSA, $\operatorname{Cot} U$, and $\mathrm{OxdD}$ and significant downregulation of CotE in OGU1 accounting for altered coat protein profile and increased sensitivity of OGU1 spores to lysozyme and chloroform. A very significant downregulation of ca. $65-\mathrm{kDa}$ CotA, as validated by 2.5 fold decreased level of its transcript must have accounted for the loss of brownish pigmentation in OGU1 (Jicinska, 1960) (Fig. 4A). Like spore coat proteins, spore coat polysaccharide synthesis proteins SpsB, SpsJ, SpsK, and cortex synthesis protein SpoVR were lost from OGU1.

Alanine utilization enzyme L-alanine dehydrogenase Ald $(\mathrm{SpoVN})$, as a sporulation and germination protein, was absent in OGU1. Other proteins of this category, which were strongly underexpressed in this strain were 3-hydroxyacylCoA dehydrogenase FadN, MRP family transition state regulator SalA, spore cortex-lytic enzyme SleB, unknown germination protein YtfJ. SalA is a phosphorylation-dependent repressor of ScoC (Derouiche et al., 2015) which is a wellknown transition state negative regulator of sporulation, exoprotease production and bac operon (Inaoka et al., 2009). DPA is essential for development of spore heat resistance and disruption of the spoVF or spoVA operons impairs sporulation (Daniel and Errington, 1993). The levels of dipicolinate synthase subunits A and B (DpaA and DpaB) as well as their transcripts were decreased 1.7 and 2.2 fold in OGU1, respectively, but with no alteration in DPA content of spores. Oligopeptide ABC transporter OppD (Spo0KD) as a component of CSF-mediated quorum sensing for initiation of sporulation and competence development was also underrepresented in OGU1 with a concomitant 3.3 times downregulation of its transcript. opp operon is among the targets of ScoC repression (Koide et al., 1999). To note, the insertional inactivation of $s p o 0 \mathrm{~K}$ operon leads to complete loss of bacilysin biosynthetic function (Yazgan et al., 2001). The germination protein YtfJ (GerW) and the unknown spore wall protein YhcQ gave an OGU1 to PY79 ratio of 0.1 and 0.3 , respectively, in 2DE-based proteomics. Quantitative RTPCR results generally well accorded with these protein representation ratios, demonstrating 2.1 and 1.6-fold decrease, respectively, in their mRNA levels.

Collectively, above-mentioned findings might indicate that bacilysin displays complex, but yet undefined functions in cellular differentiation, which phenotypically affect spore resistance and germination.

\section{Global regulatory proteins}

Some essential two-component regulator proteins that play the critical role in many cellular functions, like the adaptation to nutrient shortage, chemotaxic motility, competence development, sporulation and existence in biofilms (Hoch, 2000; Mascher et al., 2006; Gao et al., 2007) were differentially expressed between OGU1 and PY79.

In $B$. subtilis, the two-component system ResDE constitutes a key switch to ensure adaptation to anaerobiosis. ResD, which is activated upon phosphorylation by ResE, turns on the genes that function in nitrite and nitrate respiration as well as the gene coding for the anaerobic gene regulator Fnr
(Nakano et al., 2000b). We found that ResD level in OGU1 is much lower than that in the parental strain which was transcriptionally validated (3-fold decrease) by RT-qPCR assay. LuxS/AI-2 (autoinducer-2 synthase/autoinducer-2) couple form a cell-to-cell language in which AI- 2 coordinates morphogenesis and intra- and interspecific social behavior of B. subtilis. The master regulators Spo0A and SinR of pluricellular behavior have negative effect on $l u x S$ expression although LuxS has no effect on spore development (Lombardia et al., 2006). Biofilm formation and swarming behavior in undomesticated strains of B. subtilis rely on LuxS-based signalling. Intriguingly, LuxS was found 2.7 fold overexpressed and there was a 2.5-fold increase in its transcript abundance in OGU1 compared to PY79, however neither of the strains displayed biofilm formation or a remarkable swarming motility, as expected from surfactin-negative, domesticated strains (Kearns and Losick, 2003; McLoon et al., 2011).

In B. subtilis, CodY is a global pleiotropic regulator that represses during growth over 100 genes and operons, which play functions for adaptation to nutrient inavailability, such as peptide and amino acid transport systems, degradative enzymes, competence, antibiotic production, flagellin and early sporulation genes. For stimulation of its DNA-binding activity, it has to first bind to the branched-chain amino acids (BCAAs) and GTP, which may be regarded as the signals of the metabolic and energetic status of the cell (Molle et al., 2003; Brinsmade et al., 2014). Thus, limitation of nutrients at the early stationary phase is associated with a transient drop in intracellular GTP and BCAA pools, thus derepression of CodY targets occurs when cells encounter with starvation. The negative transcriptional regulator ScoC is directly repressed by CodY, therefore the potential repressive effect of ScoC can be underestimated as soon as CodY is active (Belitsky et al., 2015). However, CodY uses ScoC in its regulatory cascade to repress certain genes when it loses its own activity and thus it initiates multiple forms of cascade regulation. For instance, the $o p p$ operon which is crucial for onset of sporulation and competence is repressed by both ScoC and $\operatorname{CodY}$, but $\operatorname{cod} Y$ or $s c o C$ single mutants are not much affected. Our group showed earlier that CodY represses bac operon by co-binding with $\mathrm{AbrB}$ repressor to $\mathrm{P}_{b a c}$ (Köroğlu et al., 2011). The present proteomic analysis demonstrated that many proteins encoded by the members of CodY regulon such as CodY-activated acetate kinase (ackA) and inosine-monophosphate dehydrogenase $(g u a B)$ and CodYrepressed D-alanyl-aminopeptidase $(d p p A), \mathrm{L}$-alanine-D/Lglutamate epimerase $(y k f B)$, aconitase $(c i t B)$, alpha subunit of urease (ureC), an amidohydrolase of unknown function $(a m h X)$, the oligopeptide ABC transporter (oppD; spoOKD), intracellular serine protease (is $p A)$, an unknown protein $(y \times b D)$ and some proteins involved in branched-chain amino acid biosynthesis, ketol-acid reductoisomerase (ilvC), dihydroxy-acid dehydratase (ilvD), 3-isopropylmalate dehydratase subunit $(l e u C)$ as well as 2-oxoisovalerate dehydrogenase involved in utilization of branched-chain keto acids (lpdV) were all significantly underrepresented or absent from OGU1 when compared to PY79. Our current findings on general downregulation of the proteins of CodY and ScoC regulons with a concomitant increase of ca. 2 fold in $\operatorname{cod} Y$ transcript level in bacilysin-negative mutant led us to hypothesize that 
the absence of bacilysin during transition phase might somehow potentiates the transcription of CodY pleiotropic repressor which awaits several experimental tests.

Considering the possible impacts of bac operon silencing on early sporulation genes, the transcript abundances of the crucial proteins like phosphorelay response regulator (master regulator) Spo0A and the transition state global regulator AbrB were also determined in OGU1. In parallel to an increment in the transcript level of SpoOA, DnaA (a transcription factor repressed by $S p o 0 A$ ) transcript abundance was decreased by 2.4 fold. AbbA is activated by Spo0A and acts as an anti-repressor protein by inhibiting AbrB activity (Banse et al., 2008). Carbon catabolite control protein CcpA is known to repress $a b b A$. Interestingly, $c c p A$ transcription was found to be 2.7 fold decreased in OGU1 which might account for 2.5 fold elevated transcript abundance of $a b b A$ in this strain (Fig. 7C).

As an important protein functioning in sensory adaptation in response to attractants (Karatan et al., 2001), the response regulator $\mathrm{CheV}$ was found to be 4.3 -fold overrepresented in OGU1 with a 2.6 times elevated transcript levels. Likewise, DegU protein of DegS-DegU two-component system that regulates transition state specific events, degradative enzyme production, competence and motility (Mader et al., 2002) was 2.7-fold overrepresented in OGU1. $\operatorname{deg} U$ is known to be positively regulated by CcpA (Ishii et al., 2013). The transcript abundance of degU exhibited 3-fold increase, and its partner degS displayed 1.4-fold increase in OGU1, while $c c p A$ is strongly downregulated. These increments upon the loss of bacilysin biosynthetic function may be particularly important knowing that DegU, in a nonphosphorylated form, positively regulates bac operon as well as the monocistronic ywfH (bacG) in B. amyloliquefaciens (Mariappan et al., 2012). PhoPR is another two-component response regulator in $B$. subtilis, regulating phosphate metabolism. PhoPR is subjected to cumulative repression by ScoC and CcpA (Kaushal et al., 2010). In our work, phoP transcript abundance was found to be 1.7 times higher in OGU1.

\section{Stress response proteins}

Alternative sigma factor $\sigma^{\mathrm{B}}$ is activated in response to chemical stress and starvation in B. subtilis (Hecker et al., 2007). SigB regulon proteins underrepresented in OGU1 included $\mathrm{NadE}\left(\mathrm{NH}_{3}\right.$-dependent $\mathrm{NAD}^{+}$synthetase, so-called sporulation protein OutB), YaaH (N-acetylglucosaminidase/ survival of ethanol stress, protection of the spore), YceE (similar to tellurium resistance protein; required for survival of ethanol stress and low temperature), YceD (similar to tellurium resistance protein; required for survival of ethanol stress), $\mathrm{YceH}$ (similar to toxic anion resistance protein), and KatX (major catalase in spores for detoxification of hydrogen peroxide). On the other hand, general stress protein YtkL induced by ethanol shock and by treatment of antibiotic enduracidin (Rukmana et al., 2009) and multidrug-efflux transporter BmrA were 3.4 and 2.1 times overrepresented in OGU1, respectively. Analysis for transcript abundance validated a downregulation at the level of gene expression for YceE.

Other stress proteins which are not the members of SigB regulon and identified as significantly less abundant in OGU1 were MsrA (peptide methionine sulfoxide reductase), expression of which is elevated under disulfide stress (Leichert et al. 2003), YvaB (resistance to 2-methylhydroquinone), YgaF (resistance against oxidative stress) (Horsburgh et al., 2001), YjlD (NADH dehydrogenase, negatively regulated in stringent response), and $\mathrm{YfkO}$ (protection against $\mathrm{NaOCl}$ stress) while DnaK (class I heat shock protein) was absent. The stress proteins strongly overexpressed in OGU1 were YugI (a member of stringent response regulon) and YppQ (regeneration of methionine and restoration of protein function after oxidative damage), with 8.5 and 7.6 fold increments. AhpC (resistance against peroxide stress) and YaaN (cell envelope stress induced by salt shock) (Petersohn et al., 2001) were also increased by 2.5 and 4.4 times, respectively. Of abovementioned proteins, DnaK and YugI were selected for RTqPCR experiments and a 1.8 times decrease in $d n a K$ and a 3.6 times increase in $y u g I$ transcripts confirmed the corresponding alterations in protein levels.

\section{Secondary metabolite production and resistance}

In B. subtilis, sbo-alb operon is responsible for the production and secretion of antilisterial bacteriocin subtilosin. AlbE encoded by this operon is a signal peptide protease that acts for subtilosin export. Induction of the $s b o A$-alb operon under anaerobic conditions occurs in response to oxygen limitation and nutritional stress, which absolutely requires ResDE signal transduction complex. The operon is subjected to an independent repression by AbrB (Nakano et al., 2000a). AlbE was found as a 3-fold upregulated protein in OGU1 while ResD was simultaneously downregulated. The transcript levels of $a l b E$ and res $D$ fit well to the proteomic data in that while albE transcription showed a 2.1 -fold increase (ns, $p>0.05$ ), resD transcription showed an opposite behavior with a strong decrease of 3 fold. Therefore, AlbE overrepresentation did not seem to be a manifestation of ResDE signal transduction complex, but rather due to an elevated level of AbrB in OGU1. On the other hand, an increase in AlbE expression upon the loss of bacilysin biosynthetic function might confer a competitive adaptation since the secretion of a new antimicrobial into the environment would compensate the loss of another.

$b c e A$ and $b c e B$ genes encode the nucleotide-binding domain and the membrane-spanning domain subunits of an $\mathrm{ABC}$ transporter for bacitracin, plectasin, mersacidin and actagardine export in B. subtilis (Ohki et al., 2003). The bceRS genes that code for a two-component system reside just upstream of $b c e A B$ and when induced by bacitracin, the activated response regulator $b c e R$ upregulates $b c e A B$ genes. In the present study, BceB protein was overrepresented in OGU1. Another antibiotic transporter protein is the multidrug $\mathrm{ABC}$ transporter Bmr3 that confers multiple antibiotic resistance to $B$. subtilis (Steinfels et al., 2004). Interestingly, overexpression of both $\mathrm{BceB}$ and $\mathrm{Bmr} 3$ proteins in OGU1 was recorded.

\section{Other proteins}

As in several other Gram-positive bacteria, the dlt operon is responsible in B. subtilis for D-alanylation of lipoteichoic acids, which are the major cell wall components (Cao and 
Helmann, 2004). By generating a net positive charge on cell walls and repulsing positively charged molecules, this confers resistance to cationic antimicrobial peptides and lysozyme. DltA (D-alanine-D-alanyl carrier protein ligase) inactivation results in a higher susceptibility to such agents in B. subtilis (May et al., 2005). This protein of cell wall biosynthesis was less abundantly expressed in OGU1.

The level of MutT repair protein of mismatch recognition was shown to confer protection against oxidative stress (Castellanos-Juárez et al., 2006). MutS, another protein with the same function, was among the proteins found in elevated levels in OGU1. Three other proteins, all unknown, but increased 8.3, 7.6, and 3 times in OGU1, were YwhD, YwlG, and $\mathrm{YciC}$ (putative metallochaperone), respectively.

glmS Codes for glutamine-fructose-6-phosphate transaminase for cell wall synthesis. It is a glucosamine 6-phosphate (GlcN6P)-responsive small ribozyme, self-cleavage activity of which is triggered by binding of GlcN6P as a cofactor so that the gene is only expressed in the absence of GlcN6P (Collins et al., 2007). This protein was strongly downregulated in OGU1 in our proteome work, with a 6.25 -fold decrease in its transcript abundance. The antimicrobial action of bacilysin is due to the inhibition of GlcN6P synthase activity by its C-terminal anticapsin moiety, following the entry of bacilysin into susceptible target cells and its cleavage by intracellular proteases into the constituent amino acids. The striking downregulation of $g \operatorname{lm} S$ ribozyme upon the loss of bacilysin biosynthetic activity is indicative of elevated levels of GlcN6P, which does not seem to be the case in the bacilysin producer strain. It might then be speculated that, like other peptide pheromones, a fraction of externalized bacilysin is transported back into the producer cells to play some functions, meanwhile inhibiting GlmS, lowering intracellular GlcN6P pool, and creating conditions for GlmS expression. In the opposite situation that bacilysin is not produced by the cells, as in OGU1, $\mathrm{glmS}$ riboswitch is expected to gain selfcleavage activity which may explain a sharp decrease in $\mathrm{glmS}$ transcript levels as recorded in our work.

Antibiotic-mediated heterologous signalling involves the mechanisms by which subinhibitory concentrations of certain antibiotics trigger specific transcriptional responses in target pathogens influencing (i) their virulence, (ii) SOSresponse and other responses to stress, (iii) stabilization of mRNA and ribosome stalling, (iv) two-component systems and (v) quorum-sensing (Fajardo and Martinez, 2008). For instance, aminoglycosides and tetracycline, at subinhibitory concentrations, increase biofilm formation by Pseudomonas aeruginosa and tetracycline increases cytotoxicity of this pathogen, both being beneficial in natural environments (Linares et al., 2006). Autologous signaling, on the other hand, generally occur among members of the same species although some antibiotics may act as both autologous signals and heterologous inhibitors. Of a number of 2 -alkyl-4 $(1 \mathrm{H})$-quinolones produced by $P$. aeruginosa, the quinolone signal and 2-heptyl-4-hydroxyquinoline act as quorum-sensing signal molecules controlling the expression of many virulence genes as a function of cell population density (Heeb et al., 2011). The polyketide germicidin A and chalcone which are produced during germination of the Streptomyces coelicolor had an inhibitory effect on the germination process, by acting as quorum sensing molecules coordinating the development of their producer while repressing competitive microflora in natural environments (Cihák et al., 2017). The antitumor agent prodiginine produced by $S$. coelicolor and aromatic polyketide chromomycin produced by $S$. flaviscleroticus constitute two other examples of functions in the producer genus, as the former triggers the programmed massive death round of the vegetative mycelium during morphogenesis (Tenconi et al., 2018), and the latter acts as an antioxidant (Prajapati et al., 2019), explaining the pleiotropic phenotypes of the deletion mutants for these antibiotics. When it comes to lantibiotics and other antimicrobial peptides, the presence of the classical quorum sensing autoinducers having antimicrobial activity gives more power to the conception that antimicrobials play a dual role as signals and weapons. Especially, quorum-sensing mechanisms are widespread in lantibiotic biosynthesis, including nisin (Kuipers et al., 1995; Kleerebezem et al., 2004), subtilin (Kleerebezem et al., 2004), salivaricin A (Upton et al., 2001), streptin (Wescombe and Tagg, 2003) and mersacidin (Schmitz et al., 2006) that autoregulate their own biosyntheses. Paracrine signaling was extensively studied in recent years to understand the interaction between different co-existing subpopulations (surfactin-producing and matrix-producing, hence biofilm forming cells; sporulating cells; flagellated and motile ones; cells that secrete peptide toxins to cannibalize their siblings; and cells that become competent), all making up different cell types of $B$. subtilis multicellularity. The basic signals acting in response are ComX pheromone and the cyclic lipopeptide antibiotic surfactin, the former triggering surfactin production, and the latter triggering matrix-production and the ultimate aim looks like the maintenance of all cell types over generations (Shank and Kolter, 2011). B. subtilis 916 is capable of co-producing four different nonribosomally synthesized lipopeptide (LP) antibiotics, namely surfactin, bacillomycin (iturin family), fengycin, and a new family called locillomycin, and Luo et al. (2015), attempted to uncover the phenotypic features associated with each via the deletion of respective biosynthetic operons. Regarding the features like antifungal activity, colony morphology, hemolytic activity, swarming motility, and biofilm formation of the producer, each LP contributed in an intricate way by affecting the production of the others. In view of afore-mentioned studies and demonstrated functions, it might be plausible to attribute the proteome-wide alterations to the loss/gain-of-function in our bacilysin-negative mutant of $B$. subtilis, hence to the possibility that bacilysin itself, either directly or indirectly, acts as an autoregulator to modulate the level and timing of the distinct biological responses for adaptation to changing conditions. A small, heat-stable and proteinase K susceptible extracellular factor named FacX, which accumulates to high levels only during post-exponential growth, was reported by Ababneh et al. (2015). It was found to differ from known quorum-sensing peptides in that its activity neither requires the oligopeptide transporter systems, nor depends on SigH, Spo0A, or ComX. This study indicated the presence of yet unknown quorum sensing signals other than well-known peptide pheromones.

Remarkably, many critical two-component systems as well as global response regulators that play the critical roles in 
diverse physiological functions were differentially expressed in bacilysin-negative OGU1 cells. Our IPTG-inducible bac operon itself was theoretically suitable for complementation, however no detectable bacilysin was produced in spite of enhanced transcription of $b a c$ operon genes upon IPTG induction. The finding that OGU1 is phenotypically rescued by adding bacilysin concentrate into its cultures provided a strong clue for a connection between bacilysin and the altered functions reported herein. Although our data pointed to pleiotropic effects of bacilysin on cellular physiology in B. subtilis, it will be highly interesting to know how it takes part or cooperates in highly complex, integrated regulatory network(s).

\section{Acknowledgments}

This work was supported by the Turkish Scientific and Technical Research Council [the projects TBAG-106T535 and KBAG 116Z351] and partly by Middle East Technical University Scientific Research Funds. We would like to acknowledge Prof. Dörte Becher and Dr. Dirk Albrecht of the Institute of Microbiology, Ernst-Moritz-Arndt-University, Griefswald, Germany and Assoc. Prof. Ömür Çelikbıçak and Dr. Melis Ş. Ekiz of HUNITECH Center of Hacettepe University, Ankara for providing excellent services for MS analyses. We thank our former and present students who provided assistance in certain experiments, and Dr. Sezer Okay for his help in interpretation of comparative genome sequences.

\section{Conflict of Interest}

The authors declare no conflict of interest.

\section{References}

Ababneh, Q.O., Tindall, A.J., and Herman, J.K. 2015. A secreted factor coordinates environmental quality with Bacillus development. PLoS One 10, e0144168.

Atluri, S., Raqkouski, K., Cortezzo, D.E., and Setlow, P. 2006. Cooperativity between different nutrient receptors in germination of spores of Bacillus subtilis and reduction of this cooperativity by alterations in the GerB receptor. J. Bacteriol. 188, 28-36.

Banse, A.V., Chastanet, A., Rahn-Lee, L., Hobbs, E.C., and Losick, R. 2008. Parallel pathways of repression and antirepression governing the transition to stationary phase in Bacillus subtilis. Proc. Natl. Acad. Sci. USA 105, 15547-15552.

Barbe, V., Cruveiller, S., Kunst, F., Lenoble, P., Meurice, G., and Sekowska, A. 2009. From a consortium sequence to a unified sequence: the Bacillus subtilis 168 reference genome a decade later. Microbiology 155, 1758-1775.

Belitsky, B.R., Barbieri, G., Albertini, A.M., Ferrari, E., Strauch, M.A., and Sonenshein, A.L. 2015. Interactive regulation by the Bacillus subtilis global regulators CodY and ScoC. Mol. Microbiol. 97, 698-716.

Brinsmade, S.R., Alexander, E.L., Livny, J., Stettner, A.I., Segrè, D., Rhee, K.Y., and Sonenshein, A.L. 2014. Hierarchical expression of genes controlled by the Bacillus subtilis global regulatory protein CodY. Proc. Natl. Acad. Sci. USA 111, 8227-8232.

Cao, M. and Helmann, J.D. 2004. The Bacillus subtilis extracytoplas- mic-function $\sigma^{\mathrm{x}}$ factor regulates modification of the cell envelope and resistance to cationic antimicrobial peptides. J. Bacteriol. 186, 1136-1146.

Castellanos-Juárez, F.X., Alvarez-Alvarez, C., Yasbin, R.E., Setlow, B., Setlow, P., and Pedraza-Reyes, M. 2006. YtkD and MutT protect vegetative cells but not spores of Bacillus subtilis from oxidative stress. J. Bacteriol. 188, 2285-2289.

Čihák, M., Kameník, Z., Šmídová, K., Bergman, N., Benada, O., Kofroňová, O., Petříčková, K., and Bobek, J. 2017. Secondary metabolites produced during the germination of Streptomyces coelicolor. Front. Microbiol. 8, 2495.

Collins, J.A., Irnov, I., Baker, S., and Winkler, W.C. 2007. Mechanism of mRNA destabilization by the $g l m S$ ribozyme. Genes Dev. 21, 3356-3368.

Daniel, R.A. and Errington, J. 1993. Cloning, DNA sequence, functional analysis and transcriptional regulation of the genes encoding dipicolinic acid synthetase required for sporulation in Bacillus subtilis. J. Mol. Biol. 232, 468-483.

Derouiche, A., Shi, L., Bidnenko, V., Ventroux, M., Pigonneau, N., Franz-Wachtel, M., Kalantari, A., Nessler, S., Noirot-Gros, M.F., and Mijakovic, I. 2015. Bacillus subtilis SalA is a phosphorylation-dependent transcription regulator that represses $s c o C$ and activates the production of the exoprotease AprE. Mol. Microbiol. 97, 1195-1208.

de Hoon, M.J., Eichenberger, P., and Vitkup, D. 2010. Hierarchical evolution of the bacterial sporulation network. Curr. Biol. 20, R735-R745.

Eymann, C., Dreisbach, A., Albrecht, D., Bernhardt, J., Becher, D., Gentner, S., Tam le, T., Büttner, K., Buurman, G., Scharf, C., et al. 2004. A comprehensive proteome map of growing Bacillus subtilis cells. Proteomics 4, 2849-2876.

Eymann, C., Homuth, G., Scharf, C., and Hecker, M. 2002. Bacillus subtilis functional genomics: global characterization of the stringent response by proteome and transcriptome analysis. J. Bacteriol. 184, 2500-2520.

Fajardo, A. and Martinez, J.L. 2008. Antibiotics as signals that trigger specific bacterial responses. Curr. Opin. Microbiol. 11, 161167.

Gao, R., Mack, T.R., and Stock, A.M. 2007. Bacterial responses regulators: versatile regulatory strategies from common domains. Trends Biochem. Sci. 32, 225-234.

Görg, A., Weiss, W., and Dunn, M.J. 2004. Current two-dimensional electrophoresis technology for proteomics. Proteomics 4, 36653685.

Hamon, M.A. and Lazazzera, B.A. 2001. The sporulation transcription factor Spo0A is required for biofilm development in Bacillus subtilis. Mol. Microbiol. 42, 1199-1209.

Hecker, M., Pané-Farré, J., and Völker, U. 2007. SigB-dependent general stress response in Bacillus subtilis and related gram-positive bacteria. Annu. Rev. Microbiol. 61, 215-236.

Hecker, M., Reder, A., Fuchs, S., Pagels, M., and Engelmann, S. 2009. Physiological proteomics and stress/starvation responses in $\mathrm{Ba}$ cillus subtilis and Staphylococcus aureus. Res. Microbiol. 160, 245258.

Heeb, S., Fletcher, M.P., Chhabra, S.R., Diggle, S.P., Williams, P., and Cámara, M. 2011. Quinolones: from antibiotics to autoinducers. FEMS Microbiol. Rev. 35, 247-274.

Hoch, J.A. 2000. Two-component and phosphorelay signal transduction. Curr. Opin. Microbiol. 3, 165-170.

Horsburgh, M.J., Thackray, P.D., and Moir, A. 2001. Transcriptional responses during outgrowth of Bacillus subtilis endospores. Microbiology 147, 2933-2941.

Inaoka, T., Takahashi, K., Ohnishi-Kameyama, M., Yoshida, M., and Ochi, K. 2003. Guanine nucleotides guanosine $5^{\prime}$-diphosphate $3^{\prime}$ diphosphate and GTP co-operatively regulate the production of an antibiotic bacilysin in Bacillus subtilis. J. Biol. Chem. 278, 2169-2176. 
Inaoka, T., Wang, G., and Ochi, K. 2009. ScoC regulates bacilysin production at the transcription level in Bacillus subtilis. J. Bacteriol. 191, 7367-7371.

Ishii, H., Tanaka, T., and Ogura, M. 2013. The Bacillus subtilis response regulator gene $\operatorname{deg} U$ is positively regulated by $\mathrm{CcpA}$ and by catabolite-repressed synthesis of ClpC. J. Bacteriol. 195, 193-201.

Jicinska, E. 1960. Some physiological features of asporogenic mutants of bacilli. Mikrobiologiia 29, 195-200.

Karatan, E., Saulmon, M.M., Bunn, M.W., and Ordal, G.W. 2001. Phosphorylation of the responses regulator $\mathrm{CheV}$ is required for adaptation to attractants during Bacillus subtilis chemotaxis. J. Biol. Chem. 276, 43618-43626.

Karataş, A.Y., Çetin, S., and Özcengiz, G. 2003. The effects of insertional mutations in $\operatorname{com} Q, \operatorname{comP}, \operatorname{srfA}, \mathrm{spoOH}, \mathrm{spoOA}$ and $a b r B$ genes on bacilysin biosynthesis in Bacillus subtilis. Biochim. Biophys. Acta 1626, 51-56.

Kaushal, B., Paul, S., and Hulett, F.M. 2010. Direct regulation of Bacillus subtilis phoPR transcription by transition state regulator ScoC. J. Bacteriol. 192, 3103-3113.

Kearns, D.B. and Losick, R. 2003. Swarming motility in undomesticated Bacillus subtilis. Mol. Microbiol. 49, 581-590.

Kenig, M., Vandamme, E., and Abraham, E.P. 1976. The mode of action of bacilysin and anticapsin and biochemical properties of bacilysin-resistant mutants. J. Gen. Microbiol. 94, 46-54.

Kleerebezem, M. 2004. Quorum sensing control of lantibiotic production; nisin and subtilin autoregulate their own biosynthesis. Peptides 25, 1405-1414.

Koide, A., Perego, M., and Hoch, J.A. 1999. ScoC regulates peptide transport and sporulation initiation in Bacillus subtilis. J. Bacteriol. 181, 4114-4117.

Köroğlu, T.E., Öğülïir, İ., Mutlu, S., Yazgan-Karataş, A., and Özcengiz, G. 2011. Global regulatory systems operating in bacilysin biosynthesis in Bacillus subtilis. J. Mol. Microbiol. Biotechnol. 20, 144155.

Kuipers, O.P., Beerthuyzen, M.M., de Ruyter, P.G., Luesink, E.J., and de Vos, W.M. 1995. Autoregulation of nisin biosynthesis in Lactococcus lactis by signal transduction. J. Biol. Chem. 270, 27299-27304.

Kunst, F., Ogasawara, N., Moszer, I., Albertini, A.M., Alloni, G., Azevedo, V., Bertero, M.G., Bessières, P., Bolotin, A., Borchert, S., et al. 1997. The complete genome sequence of the Gram-positive bacterium Bacillus subtilis. Nature 390, 249-256.

Leichert, L.I., Scharf, C., and Hecker, M. 2003. Global characterization of disulfide stress in Bacillus subtilis. J. Bacteriol. 185, 19671975.

Linares, J.F., Gustafsson, I., Baquero, F., and Martinez, J.L. 2006. Antibiotics as intermicrobial signaling agents instead of weapons. Proc. Natl. Acad. Sci. USA 103, 19485-19489.

Lombardia, E., Rovetto, A.J., Arabolaza, A.L., and Grau, R.R. 2006. A LuxS-dependent cell-to-cell language regulates social behavior and development in Bacillus subtilis. J. Bacteriol. 188, 4442-4452.

Luo, C., Zhou, H., Zou, J., Wang, X., Zhang, R., Xiang, Y., and Chen, Z. 2015. Bacillomycin L and surfactin contribute synergistically to the phenotypic features of Bacillus subtilis 916 and the biocontrol of rice sheath blight induced by Rhizoctonia solani. Appl. Microbiol.Biotechnol. 99, 1897-1910.

Mader, J.U., Antelmann, H., Buder, T., Dahl, M., Hecker, M., and Homuth, G. 2002. Bacillus subtilis functional genomics: genomewide analysis of the DegS-DegU regulon by transcriptomics and proteomics. Mol. Genet. Genomics 268, 455-467.

Mahlstedt, S.A. and Walsh, C.T. 2010. Investigation of anticapsin biosynthesis reveals a four-enzyme pathway to tetrahydrotyrosine in Bacillus subtilis. Biochemistry 49, 912-923.

Mariappan, A., Makarewicz, O., Chen, X.H., and Borriss, R. 2012. Two-component responses regulator DegU controls the expression of bacilysin in plant-growth-promoting bacterium Bacillus amyloliquefaciens FZB42. J. Mol. Microbiol. Biotechnol. 22, 114-
125.

Mascher, T., Helmann, J.D., and Unden, G. 2006. Stimulus perception in bacterial signal-transducing histidine kinases. Microbiol. Mol. Biol. Rev. 70, 910-938.

May, J.J., Finking, R., Wiegeshoss, F., Weber, T.T., Bandur, N., Koert, U., and Marahiel, M.A. 2005. Inhibition of the D-alanine: Dalanyl carrier protein ligase from Bacillus subtilis increases the bacterium's susceptibility to antibiotics that target the cell wall. FEBS J. 272, 2993-3003.

McLoon, A.L., Guttenplan, S.B., Kearns, D.B., Kolter, R., and Losick, R. 2011. Tracing the domestication of a biofilm-forming bacterium. J. Bacteriol. 193, 2027-2034.

Michna, R.H., Zhu, B., Mäder, U., and Stülke, J. 2016. SubtiWiki 2.0-an integrated database for the model organism Bacillus subtilis. Nucleic Acids Res. 44, D654-D662.

Milewsky, S., Chmara, H., and Borowski, E. 1986. Anticapsin: an active site directed inhibitor of glucosamine-6-phosphate synthetase from Candida albicans. Drugs Exp. Clin. Res. 12, 577-583.

Molle, V., Nakaura, Y., Shivers, R.P., Yamaquchi, H., Losick, R., Fujita, Y., and Sonenshein, A.L. 2003. Additional targets of the $\mathrm{Ba}$ cillus subtilis global regulator CodY identified by chromatin immunoprecipitation and genome-wide transcript analysis. J. Bacteriol. 185, 1911-1922.

Nakano, M.M., Zheng, G., and Zuber, P. 2000a. Dual control of sboalb operon expression by the Spo0 and ResDE systems of signal transduction under anaerobic conditions in Bacillus subtilis. J. Bacteriol. 182, 3274-3277.

Nakano, M.M., Zhu, Y., Lacelle, M., Zhang, X., and Hulett, F.M. 2000b. Interaction of ResD with regulatory regions of anaerobically induced genes in Bacillus subtilis. Mol. Microbiol. 37, 11981207.

Neuhoff, V., Arold, N., Taube, D., and Ehrhardt, W. 1988. Improved staining of proteins in polyacrylamide gels including isoelectric focusing gels with clear background at nanogram sensitivity using Coomassie Brilliant Blue G-250 and R-250. Electrophoresis 9, 255-262.

Nicholson, W.L. and Setlow, P. 1990. Sporulation, germination and outgrowth. In Harwood, C.R. and Cutting, S.M. (eds.), Molecular Biological Methods for Bacillus, pp. 391-450. Chichester: Wiley, NY, USA.

Ohki, R., Giyanto, Tateno, K., Masuyama, W., Moriya, S., Kobayashi, K., and Ogasawara, N. 2003. The BceRS two-component regulatory system induces expression of the bacitracin transporter, BceAB, in Bacillus subtilis. Mol. Microbiol. 49, 1135-1144.

Old, W.M., Meyer-Arendt, K., Aveline-Wolf, L., Pierce, K.G., Mendoza, A., Sevinsky, J.P., Resing, K.A., and Ahn, N.G. 2005. Comparison of label-free methods for quantifying human proteins by shotgun proteomics. Mol. Cell. Proteomics 4, 1487-1502.

Özcengiz, G., Alaeddinoğlu, N.G., and Demain, A.L. 1990. Regulation of bacilysin biosynthesis by Bacillus subtilis. J. Ind. Microbiol. 6, 91-100.

Özcengiz, G. and Öğülüir, İ. 2015. Biochemistry, genetics and regulation of bacilysin biosynthesis and its significance more than an antibiotic. N. Biotechnol. 32, 612-619.

Parker, J.B. and Walsh, C.T. 2012. Olefin isomerization regiochemistries during tandem action of $\mathrm{BacA}$ and $\mathrm{BacB}$ on prephenate in bacilysin biosynthesis. Biochemistry 51, 3241-3251.

Parker, J.B. and Walsh, C.T. 2013. Action and timing of BacC and $\mathrm{BacD}$ in the late stages of biosynthesis of the dipeptide antibiotic bacilysin. Biochemistry 52, 889-901.

Perry, D. and Abraham, E.P. 1979. Transport and metabolism of bacilysin and other peptides by suspensions of Staphylococcus aureus. J. Gen. Microbiol. 115, 213-221.

Petersohn, A., Brigulia, M., Hass, S., Hoheisel, J.D., Völker, U., and Hecker, M. 2001. Global analysis of the general stress response of Bacillus subtilis. J. Bacteriol. 183, 5617-5631.

Plomp, M., Carroll, A.M., Setlow, P., and Malkin, A.J. 2014. Archi- 
tecture and assembly of the Bacillus subtilis spore coat. PLoS One 9, e108560.

Prajapati, D., Kumari, N., Dave, K., Chatupale, V., and Pohnerkar, J. 2019. Chromomycin, an antibiotic produced by Streptomyces flaviscleroticus might play a role in the resistance to oxidative stress and is essential for viability in stationary phase. Environ. Microbiol. 21, 814-826.

Rajavel, M., Mitra, A., and Gopal, B. 2009. Role of Bacillus subtilis BacB in the synthesis of bacilysin. J. Biol. Chem. 284, 31882-31892.

Ramagli, L.S. and Rodriguez, L.V. 1985. Quantitation of microgram amounts of protein in two-dimensional polyacrylamide gel electrophoresis sample buffer. Electrophoresis 6, 559-563.

Rao, X., Huang, X., Zhou, Z., and Lin, X. 2013. An improvement of the $2^{-\triangle \Delta C T}$ method for quantitative real-time polymerase chain reaction data analysis. Biostat. Bioinforma. Biomath. 3, 71-85.

Roscoe, J. and Abraham, E.P. 1966. Experiments relating to the biosynthesis of bacilysin. Biochem. J. 99, 793-800.

Rukmana, A., Morimoto, T., Takahashi, H., Giyanto, and Ogasawara, N. 2009. Assessment of transcriptional responses of Bacillus subtilis cells to the antibiotic enduracidin, which interferes with cell wall synthesis, using a high-density tiling chip. Genes Genet. Syst. 84, 253-267.

Schmitz, S., Hoffmann, A., Szekat, C., Rudd, B., and Bierbaum, G. 2006. The lantibiotic mersacidin is an autoinducing peptide. Appl. Environ. Microbiol. 72, 7270-7277.

Schroeder, J.W. and Simmons, L.A. 2013. Complete genome sequence of Bacillus subtilis strain PY79. Genome Announc. 1, e01085-13.

Shank, E.A. and Kolter, R. 2011. Extracellular signaling and multicellularity in Bacillus subtilis. Curr. Opin. Microbiol. 14, 741-747.

Shomura, Y., Hinokuchi, E., Ikeda, H., Senoo, A., Takahashi, Y., Saito, J., Komori, H., Shibata, N., Yonetani, Y., and Higuchi, Y. 2012. Structural and enzymatic characterization of BacD, an 1amino acid dipeptide ligase from Bacillus subtilis. Protein Sci. 21, 707-716.

Steil, L., Serrano, M., Henriques, A.O., and Völker, U. 2005. Genomewide analysis of temporally regulated and compartment-specific gene expression in sporulating cells of Bacillus subtilis. Microbiology 151, 399-420.

Steinborn, G., Hajirezaei, M.R., and Hofemeister, J. 2005. bac genes for recombinant bacilysin and anticapsin production in Bacillus subtilis host strains. Arch. Microbiol. 183, 71-79.

Steinfels, E., Orelle, C., Fantino, J.R., Dalmas, O., Rigaud, J.L., Denizot, F., Di Pietro, A., and Jault, J.M. 2004. Characterization of YvcC (BmrA), a multidrug $\mathrm{ABC}$ transporter constitutively expressed in Bacillus subtilis. Biochemistry 43, 7491-7502.

Takamatsu, H., Kodama, T., Imamura, A., Asai, K., Kobayashi, K., Nakayama, T., Ogasawara, N., and Watabe, K. 2000. The Bacillus subtilis yabG gene is transcribed by SigK RNA polymerase during sporulation, and yabG mutant spores have altered coat protein composition. J. Bacteriol. 182, 1883-1888.

Takamatsu, H., Kodama, T., and Watabe, K. 1999. Assembly of the CotSA coat protein into spores requires CotS in Bacillus subtilis. FEMS Microbiol. Lett. 174, 201-206.

Tenconi, L., Traxler, M.F., Hoebreck, C., van Wezel, G.P., and Rigali, S. 2018. Production of prodiginines is part of a programmed cell death process in Streptomyces coelicolor. Front. Microbiol. 9, 1742.

Upton, M., Tagg, J.R., Wescombe, P., and Jenkinson, H.F. 2001. Intraand interspecies signaling between Streptococcus salivarius and Streptococcus pyogenes mediated by SalA and SalA1 lantibiotic peptides. J. Bacteriol. 183, 3931-3938.

Walker, J.E. and Abraham, E.P. 1970. The structure of bacilysin and other products of Bacillus subtilis. Biochem. J. 118, 563-570.

Wescombe, P.A. and Tagg, J.R. 2003. Purification and characterization of streptin, a type A1 lantibiotic produced by Streptococcus pyogenes. Appl. Environ. Microbiol. 69, 2737-2747.

Yazgan, A., Özcengiz, G., and Marahiel, M.A. 2001. Tn10 insertional mutations of Bacillus subtilis that block the biosynthesis of bacilysin. Biochem. Biophys. Acta. 1518, 87-94.

Youngman, P., Perkins, J.B., and Losick, R. 1984. Construction of a cloning site near one end of Tn917 into which foreign DNA may be inserted without affecting transposition in Bacillus subtilis or expression of the transposon-borne erm gene. Plasmid 12, 1-9.

Zheng, L., Donovan, W.P., Fitz-James, P.C., and Losick, R. 1988. Gene encoding a morphogenic protein required in the assembly of the outer coat of the Bacillus subtilis endospore. Genes Dev. 2, 1047-1054.

Zhu, B. and Stülke, J. 2018. SubtiWiki in 2018: from genes and proteins to functional network annotation of the model organism Bacillus subtilis. Nucleic Acids Res. 46, D743-D748. 